\title{
Avoiding a "despair death crisis" in Europe: the drivers of human (un)sustainability
}

\section{Leonardo Becchetti $^{1} \cdot$ Gianluigi Conzo $^{1}$}

Received: 31 January 2021 / Accepted: 20 August 2021 / Published online: 8 September 2021

(C) The Author(s) 2021

\begin{abstract}
The emergence of the despair death crisis in the US stimulates researchers and policymakers to look at subjective wellbeing data from a different perspective. We wonder what can be done to avoid a similar situation in Europe, and to this purpose we analyse factors correlated with depression in the European Social Survey by considering the latter as a proxy of despair deaths. We find the strongest correlations with poor income, high-income expectations, low education, low-skilled jobs, poor social relationships, failure and shocks in affective relational life. We perform robustness checks finding that our results are robust when using alternative measures of psychological health and when instrumenting married status. If causality links between all these drivers and the dependent variable are verified and confirmed, as for marital status, we can conclude that the despair death crisis depends from a mix of material and immaterial factors (with the latter being dominant) that cannot be fully solved by mere monetary redistribution.
\end{abstract}

Keywords Depression · Life satisfaction · Happiness

JEL Classification I30 $\cdot$ I31

\section{Introduction}

The recent impressive phenomenon of the despair death crisis in the US is bringing the attention of researchers and policymakers to the problem of poverty of sense that endangers sustainability of human life. ${ }^{1}$ As well documented by Case and Deaton $(2015 \mathrm{a}, \mathrm{b})$ the "death of despair" evidence represents a clear-cut stylized fact in

\footnotetext{
1 See for instance the session titled "Despair death crisis and the future of capitalism" at the 2020 meeting of the American Economic Association (https://www.aeaweb.org/conference/2020/preliminary/ 2262).

Leonardo Becchetti

becchetti@economia.uniroma2.it

1 University of Rome Tor Vergata, Rome, Italy
} 
demographic trends in the US. Available data indicate in recent times (from 1998 to 2013) a surprising increase in mortality rates for all causes driven by a surge in mortality for suicides, opioid overdoses and alcohol related liver mortality for white non-Hispanics in the US, in spite of the marked decline in mortality in other US population groups and in almost all the other high-income countries. The effect is concentrated in the middle age (45-54) cohort and has led to a decline in life expectancy at birth in spite of the ongoing medical progress.

A tentative explanation proposed by Case and Deaton $(2015 \mathrm{a}, \mathrm{b})$ is a disadvantage progressively growing from one age cohort to the next for the low educated in terms of access to well paid jobs in the labour market, marriage, child outcomes and health. As emphasized by Deaton (2015), this disadvantage produces failure to keep up with expectations in material and social outcomes regarded (Durkheim, 1897) as a crucial driver of human despair.

Ruhm (2018) discusses the identification of the causality link beyond the despair death evidence and observes that, in the Deaton and Case (2015) interpretation, social and economic conditions lead to drug abuse and death, while a reverse causality nexus from drug abuse to worsened social and economic conditions cannot be excluded. If this is the case, the role of social and economic conditions on despair deaths would be overstated. The conclusion of Ruhm (2018) is more directed towards the reverse causality nexus since changes in economic conditions account for less than one-tenth of the rise in drug and opioid-involved mortality rates. Along this line a group of authors (Roux 2017; Ruhm 2019; Masters et al. 2018) argue that highly addictive new drugs have played per se an important role. Dow et al. (2019) seem, however, to find on the contrary evidence for causality going from economic conditions to despair deaths. They wonder whether economic policies can address the problem and find that a rise in minimum wage and earned income tax credit could reduce non-drug related suicides.

The main contributions mentioned above are much less in conflict with each other than they may seem to be. Case and Deaton (2015a, b) acknowledge that economic factors are not the only drivers of the phenomenon and that social factors matter, consistently with what argued and found by Ruhm (2018). The same concentration of the phenomenon on white non-Hispanics is a paradox and implies that poor economic conditions cannot be the only rationale explaining the phenomenon. Why black and Hispanics groups (belonging to the same low income-low education cohorts) do not display the same mortality dynamics? And why is Europe not affected in the same way by the phenomenon as shown by the 2019 report of the European Monitoring Center for Drugs and Drug Addition (EMCDDA 2019) and Alho et al. (2020)?

The difference is in part related to European policies of much more severe restrictions on opioid prescriptions and on higher reliance on treatments that combine medications for opioid-use disorder (MOUD) with psychosocial interventions (EMCDDA 2019). Higher effectiveness in actions to contrast the phenomenon needs, however, to be accompanied by policies of prevention based on empirical analyses of factors leading to addiction as those developed in our paper.

The despair death stylized facts (and paradox) suggest that it would be of great interest for the subjective wellbeing literature to look at its object of study from a 
different angle. Instead of solely focusing on the drivers of life satisfaction using values of cognitive, affective or eudaimonic wellbeing in ascending order, ${ }^{2}$ a specific investigation on the drivers that make individuals precipitate to states of depression (where the risk of despair death is much higher) would help us understand causes and device policies to prevent despair deaths.

This investigation has relevant consequences and can provide useful insights for social and economic policies. As is well known depression is one of the most common mental disorders in the world. Depression has severe economic consequences in terms of loss of productivity and health expenditure. Evans-Lacko and Knapp (2016) analyse the cost of workplace depression in terms of absenteeism and presenteeism in eight countries and find that it accounts for a ratio between 0.1 and 4.9 percent of country GDP. Becchetti et al. (2019) find that individuals declaring that their life has poor sense have higher mortality rates in the following years.

There are several different things that can cause depression ranging from biological to environmental factors.

The goal of our paper is to provide a contribution in this direction by analysing drivers of high states of depression for respondents to the European Social Survey with the goal of providing useful insights for preventing the phenomenon of the US despair death crisis in Europe.

There is obviously a trade-off in the choice of our dependent variable. On the one side, depression can hopefully not lead to suicide or other causes of despair death. On the other side it allows us to find a larger number of positive cases strongly correlated with that negative outcome and allows us to exploit the richness of survey data where we have a wide array of sociodemographic variables together with expression of tastes and values.

Our findings confirm that depression is correlated with a mix of economic and non-economic factors. If income and monetary factors play an important role, non-economic factors such as education, gender and failure and shocks from relational life are as well all important components accounting for around $85 \%$ of the explained variability of depression in our sample. These results are consistent with evidence from the life satisfaction literature where relational goods and non-monetary factors play an important role on subjective wellbeing.

\section{The dataset and the definition of the dependent variable}

The source of data for our empirical analysis is the European Social Survey (ESS). We use the fifth, sixth and seventh waves of ESS implemented in 2010, 2012 and 2014, respectively. The database contains information on health, socioeconomic status, family networks, social and political preferences of a sample of Europeans aged 15 and over. More specifically, the ESS survey is composed by 21 country-level representative samples for the following countries: Austria,

\footnotetext{
${ }^{2}$ For a survey of studies on life satisfaction see, among other, Frey and Stutzer and Becchetti and Pelloni (2013).
} 
Germany, Sweden, Netherlands, Spain, Italy, France, Denmark, Greece, Switzerland, Belgium, Israel, Czech Republic, Poland, Ireland, Luxembourg, Hungary, Portugal, Slovenia, Estonia and Croatia.

We build our dependent variable starting from an ESS question where respondents are asked whether they have been depressed most of times or all time in the last week. The construction of the question reflects the well-known fact that information on subjective wellbeing needs to be tied to an extended time period in order to avoid the influence of contingencies occurring during the interview (weather conditions, transient mood of the respondent at that moment, etc.). We are aware that the negative affect depression variable measured in a short time interval is just a proxy of a permanent depression status, even though the two variables are likely to be significantly correlated. What can be considered here is that the despair death crisis for an individual can originate also from a short-term depression shock leading the victims to start taking antidepressants or opioids that can progressively create dependence. We therefore assume that, ceteris paribus, individuals who were depressed most of the time or at all times in the week before the interview are more likely than others to be also permanently depressed. We try to control further for transient effects as well by introducing month of interview dummies picking up the effect of temporary seasonal conditions. In the robustness check presented in Sect. 4.1 we will, however, test whether our main findings are robust when using an alternative composite index of psychological health built on ESS questions concerning non-short-term related personal mood.

The answer to the depression question is positive for a non-negligible share (8.09 percent) of respondents. Surprisingly this question is not so strictly correlated to low scores of the life satisfaction or life sense questions, that is, to cognitive or eudaimonic subjective wellbeing. The number of individuals reporting a level of happiness below 5, only in part corresponds to those saying they are depressed. More specifically, we have in our sample 4319 individuals declaring both depression and happiness levels below 5, but also 6893 individuals declaring depression but happiness level not below 5 and 8901 individuals declaring happiness level below 5 but not depression. Depression therefore does not merely coincide with low scores given to the happiness question, since cases of coincidence are slightly more than 20 percent of all cases. We therefore argue that the investigation on the drivers of depression deserves a specific focus, different from a mere interpretation in the opposite direction of drivers of life satisfaction and life sense. Given that depression is more strictly correlated to despair than low levels of life satisfaction, we argue that this is the closest and most relevant focus if we want to understand and prevent despair.

The legend of the variables used in the empirical analysis is in Table 1 while descriptive findings are shown in Table 2. Slightly less than half of the sample is of male gender (46.25 percent), the average number of members in the household is 2.69. Regarding marital status around 9 percent of respondents are divorced, 9 percent widowed while 28 percent never married nor created a civil union. Around 19.5 percent of the respondents find it difficult to live with their present income. 
Table 1 Variable legend

\begin{tabular}{ll}
\hline Variable & Description \\
\hline $\begin{array}{l}\text { Dependent variables } \\
\text { Depression }\end{array}$ & $\begin{array}{c}\text { Dummy variable }=1 \text { if the respondent is depressed and } 0 \\
\text { otherwise }\end{array}$
\end{tabular}

\section{Independent variables}

Age class

Education status

Male

Income

Marital status

Household Size

Self-health

Social meeting

Placement on the left right scale

Maximum importance to compare income with other people's income

Proxy for the Wealth/Feeling about income

Wave

Country 20-29; Age 30-39; Age 40-49; Age 50-59; Age 60-69; Age 70-79; Age 80-89; Age 90+

ISCED (International Standard Classification of Education) levels: Zero level of education meaning no education or unfinished first level of education. First level (primary education or first stage basic education), second level (lower secondary or second stage of basic education), third level (upper secondary education), fourth level (postsecondary non-tertiary education), fifth level (first stage of tertiary education), sixth level (second stage of tertiary education)

Dummy variable $=1$ if the respondent's gender is male and 0 otherwise

Yearly household income after taxes and social insurance contributions

Marital status categorical variable: $1=$ Married, $2=$ Registered Partner; $3=$ Divorced $4=$ Separated; $5=$ Widowed

Number of people leaving regularly as member of household

Self-assessed health status: $1=$ Very good health, $2=$ Good health, $3=$ Fair health, $4=$ bad Health, $4=$ Very bad health

Categorical variable that measures how often socially meet with friends, relatives or colleagues: $1=$ Never, $2=$ Less than once a month, $3=$ Once a month, $4=$ Several times a month, $5=$ Once a week, $6=$ Several times a week, $7=$ Every day

Categorical variable that indicates political preferences based on a $0-10$ scale. The 0 is associated with the extreme left political preference, while 10 is associated with the extreme right political preference

Dummy variable $=1$ if the respondent believes very important the comparison with other people's income

Categorical variable that indicates the feeling about the income nowadays, in this case is used as proxy for the Wealth. $1=$ Living comfortably on present income, $2=$ Copying on present income, $3=$ Difficult on present income, $4=$ Very difficult on present income

2008 wave, 2010 wave, 2012 wave, 2014 wave, 2016 wave

Albania, Austria, Germany, Sweden, Netherlands, Norway, Spain, Finland, Italy, France, Denmark, Greece, Switzerland, Belgium, Iceland, Israel, Bulgaria, Cyprus, United Kingdom, Czech Republic, Poland, Ireland, Ukraine, Turkey, Kosovo Hungary, Slovakia, Portugal, Slovenia, Estonia, Romania, Russian Federation, Lithuania, Latvia and Croatia 
Table 1 (continued)

\begin{tabular}{ll}
\hline Variable & Description \\
\hline Month of interview & Month in which the interview is conducted \\
GHQ & $\begin{array}{l}\text { Self-administered questionnaire for identifying non-psy- } \\
\text { chotic and minor psychiatric disorders }\end{array}$ \\
\end{tabular}

\section{The econometric specification}

We estimate a specification exploiting information on depression coming from three different ESS waves (5, 6 and 7).

The estimated logit specification is

$$
\begin{aligned}
& \text { Depression }_{i, t} \\
= & \alpha_{0}+\alpha_{1} \text { Male }_{i, t}+\sum_{m} \beta_{m} \text { DIncomeDeciles }_{i, t}+\sum_{k} \gamma_{k} \text { DAgeClass }_{i, t} \\
+ & \sum_{l} \delta_{l} \text { DMaritalStatus }_{i, t}+\sum_{o} \lambda_{o} \text { DEducationStatus }_{i, t} \\
+ & \sum_{v} \zeta_{v} \text { DSocialMeeting }_{i, t}+\sum_{g} \vartheta_{g} \text { DLeftRightScale }_{i, t}+\sum_{s} \rho_{s} \text { DSelfHealt }_{i, t} \\
+ & \sum_{n} \sigma_{n} \text { DFeelingOnIncome }_{i, t}+\sum_{p} \varphi_{p} \text { DInterviewMonth }_{i, t} \\
+ & \sum_{j t} \chi_{j t} \text { DCountry }_{i}+\sum_{u} \psi_{u} \text { DWave }_{t}+\sum_{j t} \omega_{j t} \text { DCountry }_{i} * \text { DWave }_{t}+\varepsilon_{i, t}
\end{aligned}
$$

where the dependent variable (Depression) is a $0 / 1$ dummy taking unit value if the respondent answers that she/he has been depressed most of the time or all the time in the last week.

Controls include a 0/1 gender dummy taking value one for male respondents, dummies for income deciles capturing relative income position of the respondent in her/his country, 8 age class dummies to take into account the presumed nonlinear effect of ageing on depression (with the 70-79 age class being the omitted benchmark). Marital status dummies include all questionnaire items (In a civil partnership, Formerly in civil partnership, now dissolved, Formerly in civil partnership, partner died, Separated (still legally married), Separated (still in a civil partnership), Divorced, Widowed, Never married and Never in Civil Partnership) except for the married status omitted benchmark. The specification also includes education dummies based on the standard ISCED ${ }^{3}$ classification (less than lower secondary, lower secondary, lower tier upper secondary, upper tier upper secondary, advanced

\footnotetext{
${ }^{3}$ ISCED is the International Standard Classification of Education created by UNESCO to harmonize education levels of different countries into common categories (those corresponding to the education dummies introduced in our estimate). For details see http://uis.unesco.org/en/topic/international-stand ard-classification-education-isced.
} 
Table 2 Descriptive statistics

\begin{tabular}{|c|c|c|c|c|c|}
\hline Variable & Obs & Density & Variable & Obs & Density \\
\hline \multirow[t]{2}{*}{ Depression } & \multirow[t]{2}{*}{94,269} & \multirow[t]{2}{*}{0.076} & Social meeting & \multirow[t]{9}{*}{192,596} & \\
\hline & & & Never & & 0.020 \\
\hline Household's total net income & \multirow[t]{12}{*}{153,662} & & Less than once a month & & 0.089 \\
\hline 1 & & 0.106 & Once a month & & 0.101 \\
\hline 2 & & 0.115 & Several times a month & & 0.198 \\
\hline 3 & & 0.112 & Once a week & & 0.177 \\
\hline 4 & & 0.111 & Several times a week & & 0.264 \\
\hline 5 & & 0.107 & Every day & & 0.148 \\
\hline 6 & & 0.103 & & & \\
\hline 7 & & 0.099 & Self-Assessed Health & 193,656 & \\
\hline 8 & & 0.093 & Very good & & 0.234 \\
\hline 9 & & 0.074 & Good & & 0.407 \\
\hline \multirow[t]{2}{*}{10} & & \multirow[t]{2}{*}{0.075} & Fair & & 0.269 \\
\hline & & & $\mathrm{Bad}$ & & 0.072 \\
\hline Male & 193,893 & 0.462 & Very bad & & 0.015 \\
\hline \multirow[t]{2}{*}{ GHQ } & \multirow[t]{2}{*}{43,632} & \multirow[t]{2}{*}{24.71} & $\begin{array}{l}\text { Feeling about Household's } \\
\text { income nowadays }\end{array}$ & \multirow[t]{6}{*}{191,608} & \\
\hline & & & $\begin{array}{l}\text { Living comfortably on present } \\
\text { income }\end{array}$ & & 0.264 \\
\hline Age class & \multirow[t]{11}{*}{193,962} & & Copying on present income & & 0.444 \\
\hline $0-19$ & & 0.055 & Difficult on present income & & 0.195 \\
\hline $20-29$ & & 0.134 & Very difficult on present income & & 0.085 \\
\hline $30-39$ & & 0.154 & & & \\
\hline $40-49$ & & 0.166 & Placement on left right scale & 166,770 & \\
\hline $50-59$ & & 0.170 & 0 & & 0.037 \\
\hline $60-69$ & & 0.160 & 1 & & 0.024 \\
\hline $70-79$ & & 0.107 & 2 & & 0.547 \\
\hline $80-89$ & & 0.043 & 3 & & 0.095 \\
\hline \multirow[t]{2}{*}{$90+$} & & 0.007 & 4 & & 0.096 \\
\hline & & & 5 & & 0.329 \\
\hline Country & \multirow[t]{13}{*}{193,962} & & 6 & & 0.098 \\
\hline Albania & & 0.006 & 7 & & 0.107 \\
\hline Austria & & 0.031 & 8 & & 0.084 \\
\hline Belgium & & 0.036 & 9 & & 0.028 \\
\hline Bulgaria & & 0.024 & 10 & & 0.042 \\
\hline Switzerland & & 0.031 & & & \\
\hline Cyprus & & 0.011 & Education status & 193,962 & \\
\hline Czech Republic & & 0.045 & No or unfinished & & 0 \\
\hline Germany & & 0.061 & Primary & & 0.106 \\
\hline Denmark & & 0.024 & Lower Secondary & & 0.171 \\
\hline Estonia & & 0.042 & Upper Secondary & & 0.152 \\
\hline Spain & & 0.039 & Post-Secondary, non-Tertiary & & 0.209 \\
\hline Finland & & 0.041 & First level Tertiary & & 0.133 \\
\hline
\end{tabular}


Table 2 (continued)

\begin{tabular}{|c|c|c|c|c|c|}
\hline Variable & Obs & Density & Variable & Obs & Density \\
\hline France & & 0.039 & Second level Tertiary & & 0.097 \\
\hline United Kingdom & & 0.046 & & & \\
\hline Greece & & 0.013 & Marital Status & 193,962 & \\
\hline Croatia & & 0.008 & Married & & 0.019 \\
\hline Hungary & & 0.035 & Registered partner & & 0.002 \\
\hline Ireland & & 0.053 & Separated & & 0.005 \\
\hline Israel & & 0.051 & Never married & & 0.284 \\
\hline Iceland & & 0.008 & Divorced & & 0.092 \\
\hline Italy & & 0.018 & Widowed & & 0.094 \\
\hline Lithuania & & 0.042 & & & \\
\hline Netherlands & & 0.037 & Household size & 193,665 & 2.693 \\
\hline Norway & & 0.031 & & & \\
\hline Poland & & 0.035 & $\begin{array}{l}\text { Maximum importance to compare } \\
\text { income with other people's } \\
\text { income }\end{array}$ & 22,998 & 0.054 \\
\hline Portugal & & 0.035 & & & \\
\hline Russian Federation & & 0.038 & Month of interview & 192,127 & \\
\hline Sweden & & 0.034 & January & & 0.120 \\
\hline Slovenia & & 0.026 & February & & 0.088 \\
\hline Slovakia & & 0.019 & March & & 0.051 \\
\hline Ukraine & & 0.021 & April & & 0.027 \\
\hline \multirow[t]{3}{*}{ Kosovo } & & 0.006 & May & & 0.037 \\
\hline & & & June & & 0.050 \\
\hline & & & July & & 0.026 \\
\hline ESS Round & 193,962 & & August & & 0.013 \\
\hline 5 & & 0.282 & September & & 0.108 \\
\hline 6 & & 0.281 & October & & 0.192 \\
\hline 7 & & 0.207 & November & & 0.178 \\
\hline 8 & & 0.228 & December & & 0.102 \\
\hline
\end{tabular}

vocational, sub-degree, lower tertiary education, higher tertiary education). We use here as omitted benchmark education positions not harmonizable in the ISCED classification. Other controls include dummies for placement on a 0-10 left-right political scale (the extreme left 0 class being the omitted benchmark) and dummies for the frequency of social meetings (Less than once a month, Once a month, Several times a month, Once a week, Several times a week, Every day) with "never" being the omitted benchmark, feelings about the present economic conditions measured with three dummies (coping on present income, difficult, very difficult) with living comfortably being the omitted benchmark and dummies for the month of the year in which the respondent was interviewed.

The estimate finally includes dummies for each country of origin (Austria, Germany, Sweden, Netherlands, Spain, Italy, France, Denmark, Greece, Switzerland, 
Belgium, Israel, Czech Republic, Poland, Ireland, Luxembourg, Hungary, Portugal, Slovenia, Estonia and Croatia), with Albania being the omitted benchmark, dummies capturing wave effects and dummies for interacted country and wave dummies in order to capture country specific time shocks. Standard errors are clustered at country level.

\section{Empirical findings}

Full estimates findings from four specifications gradually adding variables up to the fully augmented specification presented in Sect. 3 are shown in Table 3, while Tables 8, 9, 10, 11, 12, 13, 14, 15, 16, 17 and Figs. 2, 3, 4, 5, 6, 7, 8, 9, 10, 11 in Appendix describe more in detail the effect of each regressor of interest on the probability of falling into depression in the benchmark specification. In order to check robustness of sign and magnitude of our main regressors in the model, we start from a simplified specification (Table 3, column 1) and then introduce marital status variables (column 2), social meeting and self-assessed-health variables (column 3) up to our fully augmented specification where also political opinions and importance of income comparisons are added (column 4).

A first factor significantly correlated with the dependent variable is gender, with males having a 2 percent lower probability of falling into depression vis-à-vis the omitted benchmark of females. While reverse causality is obviously excluded here (sex changes when they occur are irrelevant in term of numbers on such big samples) some forms of endogeneity cannot be excluded since omitted variables affecting both male gender and the probability of depression can exist. Note that our gender finding is in sharp contrast with evidence on drivers of the upper side of subjective wellbeing in the literature where female gender is usually found as having a positive correlation with life satisfaction and life sense. Empirical findings from studies of gender effects on depression and subjective wellbeing highlight the existence of the paradox with women being significantly more likely to be depressed while also reporting higher life satisfaction than men.

Evidence is often provided separately on one of the two sides of the paradox. Kessler et al. (1993) find that prevalence of depression in women is almost twice as large as in men. Weissmann et al. (1996) find support for this hypothesis in 10 different countries. On the second part of the paradox Nolen-Hoeksema and Rusting (1999) find that women report higher life satisfaction and more positive emotions than men, while Matteucci and Lima (2016) find higher female life satisfaction in 71 percent of cases out of 136 different country-year estimates.

Becchetti and Conzo (2021) find that the paradox works in a cross-country of 35 countries and is robust to age, education, self-assessed health, macroregion and survey round splits showing that lower women resilience and affect intensity (Diener et al. 1985) account for part of the paradox.

The effect of self-assessed health is as expected very strong. Individuals declaring that their health is very bad (the worst possible answer) have a 30 percent higher probability of being depressed than those declaring that their health is very good (the omitted benchmark) (Table 8 and Fig. 2). Even though the direct causality link 
Table 3 The determinants of depression

\begin{tabular}{|c|c|c|c|c|}
\hline \multirow[t]{2}{*}{ Variables } & (1) & (2) & (3) & (4) \\
\hline & Base & Base + MS & Base $+\mathrm{SH}+\mathrm{SM}$ & $\mathrm{Base}+\mathrm{SH}+\mathrm{SM}+\mathrm{LR}$ \\
\hline Male & $\begin{array}{l}-0.208 * * * \\
(0.028)\end{array}$ & $\begin{array}{l}-0.189 * * * \\
(0.028)\end{array}$ & $\begin{array}{l}-0.176^{* * * *} \\
(0.028)\end{array}$ & $\begin{array}{l}-0.178 * * * \\
(0.031)\end{array}$ \\
\hline \multicolumn{5}{|l|}{ Age class } \\
\hline $0-19$ & $\begin{array}{l}-0.221 * * * \\
(0.076)\end{array}$ & $\begin{array}{l}-0.235^{* * * *} \\
(0.078)\end{array}$ & $\begin{array}{l}0.215^{* * * *} \\
(0.055)\end{array}$ & $\begin{array}{l}0.294 * * * \\
(0.056)\end{array}$ \\
\hline $20-29$ & $\begin{array}{l}-0.095^{*} \\
(0.054)\end{array}$ & $\begin{array}{l}-0.084 \\
(0.055)\end{array}$ & $\begin{array}{l}0.277 * * * \\
(0.040)\end{array}$ & $\begin{array}{l}0.270 * * * \\
(0.039)\end{array}$ \\
\hline $30-39$ & $\begin{array}{l}-0.008 \\
(0.052)\end{array}$ & $\begin{array}{l}0.005 \\
(0.052)\end{array}$ & $\begin{array}{l}0.281 * * * \\
(0.035)\end{array}$ & $\begin{array}{l}0.235 * * * \\
(0.040)\end{array}$ \\
\hline $40-49$ & $\begin{array}{l}0.048 \\
(0.045)\end{array}$ & $\begin{array}{l}0.057 \\
(0.044)\end{array}$ & $\begin{array}{l}0.245^{* * *} \\
(0.032)\end{array}$ & $\begin{array}{l}0.200 * * * \\
(0.033)\end{array}$ \\
\hline $50-59$ & $\begin{array}{l}0.076 * * \\
(0.034)\end{array}$ & $\begin{array}{l}0.091 * * * \\
(0.034)\end{array}$ & $\begin{array}{l}0.183 * * * \\
(0.027)\end{array}$ & $\begin{array}{l}0.143 * * * \\
(0.027)\end{array}$ \\
\hline $60-69$ & $\begin{array}{l}-0.039 \\
(0.024)\end{array}$ & $\begin{array}{l}-0.025 \\
(0.025)\end{array}$ & $\begin{array}{l}0.026 \\
(0.027)\end{array}$ & $\begin{array}{l}0.015 \\
(0.030)\end{array}$ \\
\hline $80-89$ & $\begin{array}{l}0.028 \\
(0.030)\end{array}$ & $\begin{array}{l}-0.000 \\
(0.030)\end{array}$ & $\begin{array}{l}-0.086^{* * * *} \\
(0.032)\end{array}$ & $\begin{array}{l}-0.045 \\
(0.039)\end{array}$ \\
\hline $90+$ & $\begin{array}{l}-0.031 \\
(0.079)\end{array}$ & $\begin{array}{l}-0.061 \\
(0.079)\end{array}$ & $\begin{array}{l}-0.085 \\
(0.077)\end{array}$ & $\begin{array}{l}-0.007 \\
(0.094)\end{array}$ \\
\hline \multicolumn{5}{|c|}{ Household's income } \\
\hline 2 & $\begin{array}{l}-0.198 * * * \\
(0.023)\end{array}$ & $\begin{array}{l}-0.187^{* * *} \\
(0.024)\end{array}$ & $\begin{array}{l}-0.133 * * * \\
(0.028)\end{array}$ & $\begin{array}{l}-0.019 \\
(0.038)\end{array}$ \\
\hline 3 & $\begin{array}{l}-0.332 * * * \\
(0.030)\end{array}$ & $\begin{array}{l}-0.309 * * * \\
(0.031)\end{array}$ & $\begin{array}{l}-0.206^{* * *} \\
(0.030)\end{array}$ & $\begin{array}{l}-0.043 \\
(0.036)\end{array}$ \\
\hline 4 & $\begin{array}{l}-0.415^{* * * *} \\
(0.030)\end{array}$ & $\begin{array}{l}-0.382^{* * * *} \\
(0.031)\end{array}$ & $\begin{array}{l}-0.253 * * * \\
(0.028)\end{array}$ & $\begin{array}{l}-0.041 \\
(0.030)\end{array}$ \\
\hline 5 & $\begin{array}{l}-0.481 * * * \\
(0.033)\end{array}$ & $\begin{array}{l}-0.442 * * * \\
(0.035)\end{array}$ & $\begin{array}{l}-0.293 * * * \\
(0.032)\end{array}$ & $\begin{array}{l}-0.055 \\
(0.038)\end{array}$ \\
\hline 6 & $\begin{array}{l}-0.559 * * * \\
(0.029)\end{array}$ & $\begin{array}{l}-0.516^{* * * *} \\
(0.030)\end{array}$ & $\begin{array}{l}-0.345^{* * * *} \\
(0.032)\end{array}$ & $\begin{array}{l}-0.072 * * \\
(0.036)\end{array}$ \\
\hline 7 & $\begin{array}{l}-0.607 * * * \\
(0.038)\end{array}$ & $\begin{array}{l}-0.561 * * * \\
(0.040)\end{array}$ & $\begin{array}{l}-0.365^{* * * *} \\
(0.040)\end{array}$ & $\begin{array}{l}-0.064 \\
(0.047)\end{array}$ \\
\hline 8 & $\begin{array}{l}-0.667 * * * \\
(0.031)\end{array}$ & $\begin{array}{l}-0.619 * * * \\
(0.034)\end{array}$ & $\begin{array}{l}-0.416^{* * * *} \\
(0.034)\end{array}$ & $\begin{array}{l}-0.086 * * \\
(0.039)\end{array}$ \\
\hline 9 & $\begin{array}{l}-0.731 \text { *** } \\
(0.044)\end{array}$ & $\begin{array}{l}-0.680 \text { *** } \\
(0.046)\end{array}$ & $\begin{array}{l}-0.440 * * * \\
(0.045)\end{array}$ & $\begin{array}{l}-0.086^{*} \\
(0.051)\end{array}$ \\
\hline 10 & $\begin{array}{l}-0.851 * * * \\
(0.052)\end{array}$ & $\begin{array}{l}-0.802 * * * \\
(0.054)\end{array}$ & $\begin{array}{l}-0.557 * * * \\
(0.052)\end{array}$ & $\begin{array}{l}-0.201 * * * \\
(0.064)\end{array}$ \\
\hline Household size & $\begin{array}{l}-0.014 * * \\
(0.007)\end{array}$ & $\begin{array}{l}0.002 \\
(0.008)\end{array}$ & $\begin{array}{l}0.004 \\
(0.007)\end{array}$ & $\begin{array}{l}-0.009 \\
(0.009)\end{array}$ \\
\hline
\end{tabular}


Table 3 (continued)

\begin{tabular}{|c|c|c|c|c|}
\hline \multirow[t]{2}{*}{ Variables } & (1) & $(2)$ & (3) & (4) \\
\hline & Base & Base + MS & $\mathrm{Base}+\mathrm{SH}+\mathrm{SM}$ & $\mathrm{Base}+\mathrm{SH}+\mathrm{SM}+\mathrm{LR}$ \\
\hline \multicolumn{5}{|l|}{ Education status } \\
\hline No or unfinished & $\begin{array}{l}0.203 * * * \\
(0.027)\end{array}$ & $\begin{array}{l}0.216^{* * *} \\
(0.031)\end{array}$ & $\begin{array}{l}0.169 * * * \\
(0.031)\end{array}$ & $\begin{array}{l}0.142 * * * \\
(0.031)\end{array}$ \\
\hline Primary & $\begin{array}{l}0.403 * * * \\
(0.034)\end{array}$ & $\begin{array}{l}0.407 * * * \\
(0.034)\end{array}$ & $\begin{array}{l}0.231 * * * \\
(0.036)\end{array}$ & $\begin{array}{l}0.197 * * * \\
(0.040)\end{array}$ \\
\hline Lower Secondary & $\begin{array}{l}0.317 * * * \\
(0.026)\end{array}$ & $\begin{array}{l}0.317 * * * \\
(0.026)\end{array}$ & $\begin{array}{l}0.196 * * * \\
(0.030)\end{array}$ & $\begin{array}{l}0.158 * * * \\
(0.035)\end{array}$ \\
\hline Upper Secondary & $\begin{array}{l}0.155^{* * * *} \\
(0.027)\end{array}$ & $\begin{array}{l}0.158 * * * \\
(0.027)\end{array}$ & $\begin{array}{l}0.087 * * * \\
(0.028)\end{array}$ & $\begin{array}{l}0.051 * \\
(0.027)\end{array}$ \\
\hline Post-Secondary & $\begin{array}{l}0.130 * * * \\
(0.027)\end{array}$ & $\begin{array}{l}0.132 * * * \\
(0.027)\end{array}$ & $\begin{array}{l}0.087 * * * \\
(0.025)\end{array}$ & $\begin{array}{l}0.078 * * * \\
(0.030)\end{array}$ \\
\hline First Level Tertiary & $\begin{array}{l}0.082 * * * \\
(0.029)\end{array}$ & $\begin{array}{l}0.083 * * * \\
(0.029)\end{array}$ & $\begin{array}{l}0.052 * \\
(0.027)\end{array}$ & $\begin{array}{l}0.031 \\
(0.030)\end{array}$ \\
\hline Second Level Tertiary & $\begin{array}{l}0.017 \\
(0.033)\end{array}$ & $\begin{array}{l}0.019 \\
(0.033)\end{array}$ & $\begin{array}{l}0.025 \\
(0.034)\end{array}$ & $\begin{array}{l}0.024 \\
(0.040)\end{array}$ \\
\hline \multicolumn{5}{|l|}{ Month of interview } \\
\hline February & $\begin{array}{l}-0.048 \\
(0.038)\end{array}$ & $\begin{array}{l}-0.049 \\
(0.038)\end{array}$ & $\begin{array}{l}-0.049 \\
(0.043)\end{array}$ & $\begin{array}{l}-0.056 \\
(0.046)\end{array}$ \\
\hline March & $\begin{array}{l}-0.004 \\
(0.063)\end{array}$ & $\begin{array}{l}-0.008 \\
(0.063)\end{array}$ & $\begin{array}{l}0.005 \\
(0.066)\end{array}$ & $\begin{array}{l}-0.001 \\
(0.066)\end{array}$ \\
\hline April & $\begin{array}{l}0.058 \\
(0.089)\end{array}$ & $\begin{array}{l}0.059 \\
(0.088)\end{array}$ & $\begin{array}{l}0.020 \\
(0.081)\end{array}$ & $\begin{array}{l}0.043 \\
(0.101)\end{array}$ \\
\hline May & $\begin{array}{l}-0.058 \\
(0.104)\end{array}$ & $\begin{array}{l}-0.061 \\
(0.103)\end{array}$ & $\begin{array}{l}-0.046 \\
(0.096)\end{array}$ & $\begin{array}{l}-0.030 \\
(0.118)\end{array}$ \\
\hline June & $\begin{array}{l}-0.109 \\
(0.108)\end{array}$ & $\begin{array}{l}-0.110 \\
(0.107)\end{array}$ & $\begin{array}{l}-0.104 \\
(0.117)\end{array}$ & $\begin{array}{l}-0.072 \\
(0.147)\end{array}$ \\
\hline July & $\begin{array}{l}-0.265^{* * * *} \\
(0.080)\end{array}$ & $\begin{array}{l}-0.261 * * * \\
(0.078)\end{array}$ & $\begin{array}{l}-0.249 * * * \\
(0.090)\end{array}$ & $\begin{array}{l}-0.262 * * * \\
(0.097)\end{array}$ \\
\hline August & $\begin{array}{l}-0.192 * * * \\
(0.060)\end{array}$ & $\begin{array}{l}-0.190 * * * \\
(0.059)\end{array}$ & $\begin{array}{l}-0.175^{* * * *} \\
(0.058)\end{array}$ & $\begin{array}{l}-0.137 * * \\
(0.062)\end{array}$ \\
\hline September & $\begin{array}{l}-0.052 \\
(0.041)\end{array}$ & $\begin{array}{l}-0.053 \\
(0.041)\end{array}$ & $\begin{array}{l}-0.058 \\
(0.038)\end{array}$ & $\begin{array}{l}-0.039 \\
(0.040)\end{array}$ \\
\hline October & $\begin{array}{l}-0.042 \\
(0.045)\end{array}$ & $\begin{array}{l}-0.041 \\
(0.044)\end{array}$ & $\begin{array}{l}-0.042 \\
(0.042)\end{array}$ & $\begin{array}{l}-0.030 \\
(0.043)\end{array}$ \\
\hline November & $\begin{array}{l}-0.024 \\
(0.032)\end{array}$ & $\begin{array}{l}-0.025 \\
(0.032)\end{array}$ & $\begin{array}{l}-0.034 \\
(0.028)\end{array}$ & $\begin{array}{l}-0.027 \\
(0.030)\end{array}$ \\
\hline December & $\begin{array}{l}0.033 \\
(0.031)\end{array}$ & $\begin{array}{l}0.030 \\
(0.031)\end{array}$ & $\begin{array}{l}0.030 \\
(0.030)\end{array}$ & $\begin{array}{l}0.041 \\
(0.032)\end{array}$ \\
\hline \multicolumn{5}{|l|}{ Marital Status } \\
\hline Registered partner & & $\begin{array}{l}0.175^{* * *} \\
(0.058)\end{array}$ & $\begin{array}{l}0.144 * * \\
(0.061)\end{array}$ & $\begin{array}{l}0.109 \\
(0.069)\end{array}$ \\
\hline
\end{tabular}


Table 3 (continued)

\begin{tabular}{|c|c|c|c|c|}
\hline \multirow[t]{2}{*}{ Variables } & (1) & (2) & (3) & (4) \\
\hline & Base & Base + MS & Base $+\mathrm{SH}+\mathrm{SM}$ & Base $+\mathrm{SH}+\mathrm{SM}+\mathrm{LR}$ \\
\hline \multirow[t]{2}{*}{ Separated } & & $0.300 * * *$ & $0.302 * * *$ & $0.319 * * *$ \\
\hline & & $(0.070)$ & $(0.067)$ & $(0.069)$ \\
\hline \multirow[t]{2}{*}{ Divorced } & & $0.162 * * *$ & $0.166^{* * * *}$ & $0.125 * * *$ \\
\hline & & $(0.022)$ & $(0.022)$ & $(0.025)$ \\
\hline \multirow[t]{2}{*}{ Widowed } & & $0.194 * * *$ & $0.165 * * *$ & $0.160 * * *$ \\
\hline & & $(0.025)$ & $(0.026)$ & $(0.028)$ \\
\hline \multirow[t]{2}{*}{ Never Married } & & $0.064 * * *$ & $0.077 * * *$ & $0.056 * * *$ \\
\hline & & $(0.017)$ & $(0.018)$ & $(0.020)$ \\
\hline \multicolumn{5}{|l|}{ Self-assessed health } \\
\hline \multirow[t]{2}{*}{ Good } & & & $0.196 * * *$ & $0.206 * * *$ \\
\hline & & & $(0.029)$ & $(0.030)$ \\
\hline \multirow[t]{2}{*}{ Fair } & & & $0.599 * * *$ & $0.574 * * *$ \\
\hline & & & $(0.034)$ & $(0.032)$ \\
\hline \multirow[t]{2}{*}{ Bad } & & & $1.163 * * *$ & $1.087 * * *$ \\
\hline & & & $(0.043)$ & $(0.043)$ \\
\hline \multirow[t]{2}{*}{ Very Bad } & & & $1.665^{* * *}$ & $1.568 * * *$ \\
\hline & & & $(0.067)$ & $(0.070)$ \\
\hline \multicolumn{5}{|l|}{ Social meeting } \\
\hline \multirow[t]{2}{*}{ Less than once a month } & & & $-0.271 * * *$ & $-0.291 * * *$ \\
\hline & & & $(0.053)$ & $(0.056)$ \\
\hline \multirow[t]{2}{*}{ Once a month } & & & $-0.434 * * *$ & $-0.412 * * *$ \\
\hline & & & $(0.054)$ & $(0.061)$ \\
\hline \multirow[t]{2}{*}{ Several times a month } & & & $-0.565 * * *$ & $-0.565 * * *$ \\
\hline & & & $(0.048)$ & $(0.050)$ \\
\hline \multirow[t]{2}{*}{ Once a week } & & & $-0.513 * * *$ & $-0.498 * * *$ \\
\hline & & & $(0.051)$ & $(0.052)$ \\
\hline \multirow[t]{2}{*}{ Several times a week } & & & $-0.599 * * *$ & $-0.568 * * *$ \\
\hline & & & $(0.049)$ & $(0.048)$ \\
\hline \multirow[t]{2}{*}{ Every day } & & & $-0.530 * * *$ & $-0.519 * * *$ \\
\hline & & & $(0.045)$ & $(0.048)$ \\
\hline \multicolumn{5}{|l|}{ Placement on left right scale } \\
\hline \multirow[t]{2}{*}{1} & & & & $-0.093 * *$ \\
\hline & & & & $(0.041)$ \\
\hline \multirow[t]{2}{*}{2} & & & & $-0.073 *$ \\
\hline & & & & $(0.042)$ \\
\hline \multirow[t]{2}{*}{3} & & & & $-0.074 * *$ \\
\hline & & & & $(0.032)$ \\
\hline \multirow[t]{2}{*}{4} & & & & -0.045 \\
\hline & & & & $(0.039)$ \\
\hline \multirow[t]{2}{*}{5} & & & & $-0.113 * * *$ \\
\hline & & & & $(0.029)$ \\
\hline
\end{tabular}


Table 3 (continued)

\begin{tabular}{|c|c|c|c|c|}
\hline \multirow[t]{2}{*}{ Variables } & $(1)$ & (2) & (3) & (4) \\
\hline & Base & Base + MS & Base $+\mathrm{SH}+\mathrm{SM}$ & $\mathrm{Base}+\mathrm{SH}+\mathrm{SM}+\mathrm{LR}$ \\
\hline \multirow[t]{2}{*}{6} & & & & $-0.101 * * *$ \\
\hline & & & & $(0.037)$ \\
\hline \multirow[t]{2}{*}{7} & & & & $-0.134 * * *$ \\
\hline & & & & $(0.039)$ \\
\hline \multirow[t]{2}{*}{8} & & & & -0.050 \\
\hline & & & & $(0.035)$ \\
\hline \multirow[t]{2}{*}{9} & & & & $-0.114 * *$ \\
\hline & & & & $(0.057)$ \\
\hline \multirow[t]{2}{*}{10} & & & & -0.052 \\
\hline & & & & $(0.052)$ \\
\hline \multicolumn{5}{|c|}{ Feeling about Household's income nowadays } \\
\hline \multirow[t]{2}{*}{ Copying on present income } & & & & $0.103 * * *$ \\
\hline & & & & $(0.023)$ \\
\hline \multirow[t]{2}{*}{ Difficult on present income } & & & & $0.350 * * *$ \\
\hline & & & & $(0.032)$ \\
\hline \multirow[t]{2}{*}{ Very difficult on present income } & & & & $0.659 * * *$ \\
\hline & & & & $(0.040)$ \\
\hline \multicolumn{5}{|l|}{ Wave } \\
\hline \multirow[t]{2}{*}{6} & $-0.258 * * *$ & $-0.258 * * *$ & $-0.221 * * *$ & $-0.250 * * *$ \\
\hline & $(0.015)$ & $(0.014)$ & $(0.013)$ & $(0.015)$ \\
\hline \multirow[t]{2}{*}{7} & $-0.163^{* * *}$ & $-0.139 * * *$ & $-0.069 * * *$ & -0.019 \\
\hline & $(0.015)$ & $(0.016)$ & $(0.014)$ & $(0.014)$ \\
\hline Country $\times$ Wave Dummies & Yes & Yes & Yes & Yes \\
\hline Country dummies & Yes & Yes & Yes & Yes \\
\hline \multirow[t]{2}{*}{ Constant } & $-0.523 * * *$ & $-0.649 * * *$ & $-0.876^{* * *}$ & $-1.193 * * *$ \\
\hline & $(0.050)$ & $(0.049)$ & $(0.068)$ & $(0.075)$ \\
\hline Observations & 105,298 & 105,298 & 104,485 & 92,563 \\
\hline R-Squared & 0.094 & 0.096 & 0.172 & 0.177 \\
\hline
\end{tabular}

Omitted benchmarks: age class between 70 and 79; first (lowest income) class of the household's net income; "Upper Tertiary" class for education status; Month of "February" for Month of interview; "Married" class for marital status; "Very Good" class of self-assessed health; "Never" class of social meeting; the 0 (extreme left) class of placement in the political opinion left-right scale; "Living Comfortably on present income" in the Feeling about Household's income question, Albania for country dummies

$M S$ marital status levels also taken into account, $S H$ self-health levels also taken into account, $S M$ social meeting levels also taken into account, $L R$ placement on left right scale also taken into account. Sample survival indicates the marginal effects of the covariates on the survival across waves. Clustered (for country) standard errors in parentheses

${ }^{* * *} p<0.01, * * p<0.05, * p<0.1$

seems the best candidate to explain this correlation, reverse causality here cannot be excluded: if it is likely that a serious health shock brings depression, it is possible that depressed individuals are more likely to suffer from health deterioration as well. 

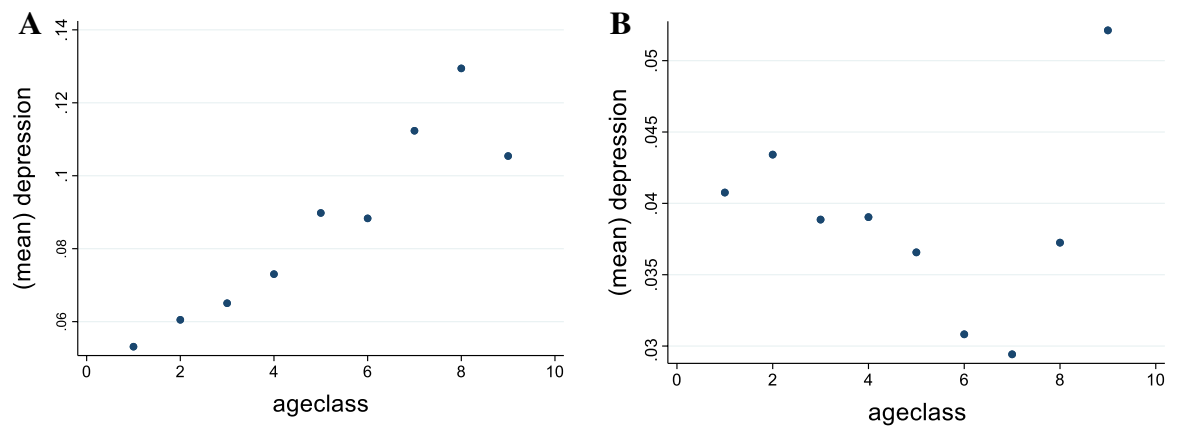

Fig. 1 a Share of depressed respondents and age classes. b Share of depressed respondents per age class (individuals with very good or good self-assessed health status only). Vertical axis: share of respondents declaring they have been depressed most of times or all time in the last week. Horizontal axis: age class dummies. 1: 0-19; 2: 20-29; 3: 30-39; 4: 40-49; 5: 50-59; 6: 60-69; 7: 70-79; 8: 80-89; 9: 90+

When we look at age results, we find that the seventies are the best decade $(0.5$ percent lower probability of falling into depression than the omitted benchmark of the 70es), while all younger age cohorts register a higher probability of depression probably due to much higher expectations, time pressure and commitment ( 3 percent higher probability for those on the thirties) (Table 9 and Fig. 3). These findings are consistent with the Case and Deaton $(2015 \mathrm{a}, \mathrm{b})$ interpretation of the despair death phenomenon in the US concentrating in middle age cohorts where high expectations are an important concurring factor. They as well suggest that ageing is not per se a depressing factor once controlling for health and all other included regressors. More specifically, based on our findings, it is not ageing per se that can lead to depression but the combination of poorer relational life and reduced health that may associate depression with age. Our interpretation is confirmed when we compare these findings with descriptive evidence on the share of depressed for different age cohorts. In Fig. 1a we do not control for self-assessed health and the inverse U-shaped effect on depression disappears with the share of depressed getting higher as far as age grows. However, when we plot values of the same variable limiting the analysis to respondents declaring very good or good self-assessed health the U-shape comes back (with the exception of those aged 90 and above) (Fig. 1b). In other terms the share of depressed grows with age (with the notable exception of those aged 90 and above) only when we do not control for health conditions.

Marital status findings are not at odds with the hypothesis that investing in an affective relationship with a partner is a high risk activity (as it occurs for any relational good where there is a coordination failure problem since the individual investment is not enough to guarantee the enjoyment of the good) (Table 10 and Fig. 4). ${ }^{4}$

\footnotetext{
4 The literature defines relational good as the enjoyment arising from the common consent or quality of relationship with other human beings in a common activity. As such, relational goods are a particular kind of local public goods characterised by local non excludability and anti-rivalry. (Gui 1987; Uhlaner 1989; Becchetti et al. 2011; Antoci et al. 2007; Corneo 2005; Jenkins and Osberg 2004 and Randon et al. 2008). This is because a relationship (in a club, in a social meeting) may be enjoyed only by those who are invited to take part (local non excludability). At the same time relational goods are more than simply non rival goods as typical public goods. This is because other human beings are essential for their enjoy-
} 
Bad outcomes such as separation, divorce and widowhood increase significantly the probability of depression vis-à-vis the omitted benchmark of the married and/ or civil union status. The magnitude of the effect is much higher in case of separation (around 4 percent against 1.6-1.7 percent). Non-investing at all in affective relationships (the never married/never civil union status) also has a slight potentially depressing effect ( 0.6 percent).

Placement into higher-income deciles has a progressive depression reducing effect with individuals in the top income deciles registering a 5 percent lower probability of depression than those in the lowest income decile (Table 11 and Fig. 5). Again, this is a finding in contrast with what found in the life satisfaction literature with the Easterlin paradox, even though the core of the paradox is a non-positive relationship between per capita GDP growth and the share of very happy people. ${ }^{5}$

Human relationships (beyond affective with partner) are again an important driver since respondents declaring to meet for social (recreational) purposes with friends, relatives or colleagues every day register an around 9 percent lower probability of depression than those never doing it (Table 12 and Fig. 6). As for the case of health, endogeneity and reverse causality cannot be excluded here since individuals with more extroverted psychological traits are more likely to have a lively social life and less likely to be depressed. As well, absence of depression leads to a livelier social life. ${ }^{6}$

Education has an important direct effect since individuals with less than lower secondary degree have an around 3 percent higher probability of depression than those with high level post-university degree (Table 13 and Fig. 7). In order to evaluate the total effect of education on depression, we should sum up to this direct effect two indirect effects accruing through income and health if we consider the microeconomic literature on returns to schooling and the literature on the nexus between education and health. Self-declared political orientation at the extreme left is the worst in terms of effects on depression indicating broadly a 1 percent higher probability of depression than all other locations.

\footnotetext{
Footnote 4 (continued)

ment and not just non rival for the enjoyment itself (anti-rivalry). Quality of relational goods depends on mutual investment that is subject to coordination failure. Individual will be a necessary but not sufficient condition for production, consumption and investment in them since the latter require consent and participation also from the partners with whom the relational good is produced.

5 The origin of the paradox in the descriptive evidence about the decoupling between per capita GDP and the share of very happy people in the US after the Second World War. The result therefore relates to the aggregate change of the two variables over time and not to a within effect for single respondents. The paradox is confirmed by Frey and Stutzer (2002) for a large sample of countries, and by Blanchflower and Oswald (2004) for the United States, United Kingdom, Belgium and Japan, between the early 1970s and late 1990s. Stevenson and Wolfers (2008) find that the decoupling does not occur when looking at per capita GDP and individual income. Easterlin and Angelescu (2009) argue that the paradox remains when looking at long term nexus between happiness and per capita GDP at country level. Bartolini et al. (2009) observe that deterioration of social capital accounts for part of the paradox in the US.

${ }^{6}$ Becchetti et al. (2008) find that the relationship between social life and subjective wellbeing hides a two-way causation when the dependent variable is life satisfaction.
} 
If we interpret magnitudes of our coefficients in terms of ranking, we observe that health is the strongest driver, followed by social relationships, affective relationships with the partner, income and education.

In our specification, we introduce an income satisfaction variable as well. EES respondents are asked whether it is possible to live comfortably with their present income. The variable captures income and wealth related factors not measured by other regressors (income deciles, number of household members) but also income expectations. The variable is strongly significant. Individuals giving the more negative response (very difficult to live comfortably with present income) have a 9 percent higher probability of getting depressed (Table 16 and Fig. 10).

Concerning country effects, only one country (the Czech Republic) reports a positive and significant coefficient, that is, a higher probability for respondents living there to be depressed with respect to the omitted benchmark of Albania. Other two countries (Poland and Hungary) are not significantly different from Albania (Table 4). All other countries have negative sign (lower probability of falling into depression vis-à-vis Albania). As is well known, country effects are affected by cultural factors and by the same meaning given to the word "depression" that may vary across cultures. Unfortunately, the ESS survey does not contain vignettes that are used in the literature to control for these cultural effects. ${ }^{7}$

In order to calculate the relative weight of monetary versus non-monetary variables in our specification, we run an estimate without the two money-related set of variables - income dummies and dummies on feeling about income conditions (capturing with income satisfaction all the variables affecting economic conditions beyond income) - and we compare it with our fully augmented estimate including the two income related set off variables. We find that monetary factors increase goodness of fit by around $15 \%$. We must, however, consider that some of the interacted country/wave effects are likely to capture economic shocks that produce changes in economic conditions, even though such factors should be captured at individual level by the three income related variables. Most of the explained variability of depression is therefore explained by nonmonetary variables such as gender, age, education, self-assessed-health and intensity of relational life.

\subsection{Robustness check on alternative dependent variable}

The negative affect variable measured in a short time interval is just a proxy of a permanent depression status, even though we argue that the two variables are likely to be significantly correlated.

\footnotetext{
7 Vignettes are widely used in the empirical literature (when available) to correct for cultural differences by using scores given by respondents to the same observed situation (Corrado and Weeks 2010; King and Wand 2007). The approach has however limits and it works only when the two assumptions of vignette equivalence (vignette scenarios perceived without significant differences by respondents) and response consistency (use of response category in the same way in self-assessment and evaluation of the vignette scenario) are met. These two assumption are however often rejected in empirical tests (d'Uva et al. 2009; Ferrer-I-Carbonell et al. 2011).
} 
Table 4 Country effects

\begin{tabular}{|c|c|c|c|c|}
\hline \multirow[t]{2}{*}{ Variables } & (1) & (2) & (3) & (4) \\
\hline & Base & Base + MS & Base $+\mathrm{SH}+\mathrm{SM}$ & Base $+\mathrm{SH}+\mathrm{SM}+\mathrm{LR}$ \\
\hline \multicolumn{5}{|l|}{ Country } \\
\hline Austria & $\begin{array}{l}-0.530 * * * \\
(0.053)\end{array}$ & $\begin{array}{l}-0.579 * * * \\
(0.055)\end{array}$ & $\begin{array}{l}-0.568^{* * * *} \\
(0.046)\end{array}$ & $\begin{array}{l}-0.574 * * * \\
(0.046)\end{array}$ \\
\hline Belgium & $\begin{array}{l}-0.367 * * * \\
(0.025)\end{array}$ & $\begin{array}{l}-0.402 * * * \\
(0.027)\end{array}$ & $\begin{array}{l}-0.308^{* * * *} \\
(0.024)\end{array}$ & $\begin{array}{l}-0.273 * * * \\
(0.033)\end{array}$ \\
\hline Bulgaria & $\begin{array}{l}-0.440 * * * \\
(0.039)\end{array}$ & $\begin{array}{l}-0.452 * * * \\
(0.042)\end{array}$ & $\begin{array}{l}-0.506^{* * * *} \\
(0.035)\end{array}$ & $\begin{array}{l}-0.587 * * * \\
(0.036)\end{array}$ \\
\hline Switzerland & $\begin{array}{l}-0.491 * * * \\
(0.043)\end{array}$ & $\begin{array}{l}-0.530 * * * \\
(0.044)\end{array}$ & $\begin{array}{l}-0.371 * * * \\
(0.038)\end{array}$ & $\begin{array}{l}-0.332 * * * \\
(0.047)\end{array}$ \\
\hline Cyprus & $\begin{array}{l}-0.626^{* * *} \\
(0.044)\end{array}$ & $\begin{array}{l}-0.666^{* * * *} \\
(0.046)\end{array}$ & $\begin{array}{l}-0.639 * * * \\
(0.039)\end{array}$ & $\begin{array}{l}-0.631 * * * \\
(0.037)\end{array}$ \\
\hline Czech Republic & $\begin{array}{l}-0.157 * * * \\
(0.026)\end{array}$ & $\begin{array}{l}-0.209 * * * \\
(0.030)\end{array}$ & $\begin{array}{l}-0.164 * * * \\
(0.026)\end{array}$ & $\begin{array}{l}-0.177 * * * \\
(0.030)\end{array}$ \\
\hline Germany & $\begin{array}{l}-0.388^{* * *} \\
(0.036)\end{array}$ & $\begin{array}{l}-0.420 * * * \\
(0.037)\end{array}$ & $\begin{array}{l}-0.488^{* * * *} \\
(0.031)\end{array}$ & $\begin{array}{l}-0.434 * * * \\
(0.041)\end{array}$ \\
\hline Denmark & $\begin{array}{l}-0.675^{* * *} \\
(0.033)\end{array}$ & $\begin{array}{l}-0.710 * * * \\
(0.035)\end{array}$ & $\begin{array}{l}-0.625 * * * \\
(0.031)\end{array}$ & $\begin{array}{l}-0.535 * * * \\
(0.041)\end{array}$ \\
\hline Estonia & $\begin{array}{l}-0.058^{* *} \\
(0.027)\end{array}$ & $\begin{array}{l}-0.093 * * * \\
(0.028)\end{array}$ & $\begin{array}{l}-0.282 * * * \\
(0.021)\end{array}$ & $\begin{array}{l}-0.261 * * * \\
(0.028)\end{array}$ \\
\hline Spain & $\begin{array}{l}-0.582 * * * \\
(0.021)\end{array}$ & $\begin{array}{l}-0.613 * * * \\
(0.023)\end{array}$ & $\begin{array}{l}-0.635^{* * * *} \\
(0.019)\end{array}$ & $\begin{array}{l}-0.605 * * * \\
(0.032)\end{array}$ \\
\hline Finland & $\begin{array}{l}-0.930 * * * \\
(0.045)\end{array}$ & $\begin{array}{l}-0.976 * * * \\
(0.048)\end{array}$ & $\begin{array}{l}-0.954 * * * \\
(0.039)\end{array}$ & $\begin{array}{l}-0.953 * * * \\
(0.042)\end{array}$ \\
\hline France & $\begin{array}{l}-0.281 * * * \\
(0.027)\end{array}$ & $\begin{array}{l}-0.319 * * * \\
(0.029)\end{array}$ & $\begin{array}{l}-0.259 * * * \\
(0.025)\end{array}$ & $\begin{array}{l}-0.183 * * * \\
(0.033)\end{array}$ \\
\hline United Kingdom & $\begin{array}{l}-0.437 * * * \\
(0.050)\end{array}$ & $\begin{array}{l}-0.496 * * * \\
(0.055)\end{array}$ & $\begin{array}{l}-0.488^{* * * *} \\
(0.045)\end{array}$ & $\begin{array}{l}-0.450 * * * \\
(0.047)\end{array}$ \\
\hline Hungary & $\begin{array}{l}0.155^{*} \\
(0.090)\end{array}$ & $\begin{array}{l}0.093 \\
(0.091)\end{array}$ & $\begin{array}{l}-0.181 * * \\
(0.089)\end{array}$ & $\begin{array}{l}-0.314 * * * \\
(0.101)\end{array}$ \\
\hline Ireland & $\begin{array}{l}-0.730 * * * \\
(0.041)\end{array}$ & $\begin{array}{l}-0.780 * * * \\
(0.045)\end{array}$ & $\begin{array}{l}-0.713^{* * * *} \\
(0.040)\end{array}$ & $\begin{array}{l}-0.700 * * * \\
(0.040)\end{array}$ \\
\hline Israel & $\begin{array}{l}-0.234 * * * \\
(0.045)\end{array}$ & $\begin{array}{l}-0.281 * * * \\
(0.047)\end{array}$ & $\begin{array}{l}-0.296^{* * * *} \\
(0.046)\end{array}$ & $\begin{array}{l}-0.358 * * * \\
(0.042)\end{array}$ \\
\hline Iceland & $\begin{array}{l}-0.522^{* * * *} \\
(0.016)\end{array}$ & $\begin{array}{l}-0.548 * * * \\
(0.018)\end{array}$ & $\begin{array}{l}-0.382^{* * * *} \\
(0.017)\end{array}$ & $\begin{array}{l}-0.206 * * * \\
(0.026)\end{array}$ \\
\hline Italy & $\begin{array}{l}-0.290 * * * \\
(0.050)\end{array}$ & $\begin{array}{l}-0.302^{* * * *} \\
(0.049)\end{array}$ & $\begin{array}{l}-0.239 * * * \\
(0.058)\end{array}$ & $\begin{array}{l}-0.122 * \\
(0.068)\end{array}$ \\
\hline Lithuania & $\begin{array}{l}-0.371^{* * * *} \\
(0.081)\end{array}$ & $\begin{array}{l}-0.433 * * * \\
(0.083)\end{array}$ & $\begin{array}{l}-0.626^{* * * *} \\
(0.078)\end{array}$ & $\begin{array}{l}-0.634 * * * \\
(0.089)\end{array}$ \\
\hline Latvia & $\begin{array}{l}-0.120 * * \\
(0.055)\end{array}$ & $\begin{array}{l}-0.154 * * * \\
(0.051)\end{array}$ & $\begin{array}{l}-0.251^{* * * *} \\
(0.058)\end{array}$ & $\begin{array}{l}-0.229 * * * \\
(0.059)\end{array}$ \\
\hline
\end{tabular}


Table 4 (continued)

\begin{tabular}{|c|c|c|c|c|}
\hline \multirow[t]{2}{*}{ Variables } & (1) & (2) & (3) & (4) \\
\hline & Base & Base + MS & $\mathrm{Base}+\mathrm{SH}+\mathrm{SM}$ & Base $+\mathrm{SH}+\mathrm{SM}+\mathrm{LR}$ \\
\hline \multirow[t]{2}{*}{ Netherlands } & $-0.679 * * *$ & $-0.719 * * *$ & $-0.620 * * *$ & $-0.549 * * *$ \\
\hline & $(0.030)$ & $(0.032)$ & $(0.027)$ & $(0.038)$ \\
\hline \multirow[t]{2}{*}{ Norway } & $-0.700 * * *$ & $-0.735^{* * *}$ & $-0.692 * * *$ & $-0.681 * * *$ \\
\hline & $(0.043)$ & $(0.043)$ & $(0.038)$ & $(0.045)$ \\
\hline \multirow[t]{2}{*}{ Poland } & $-0.155^{* * *}$ & $-0.180 * * *$ & $-0.242 * * *$ & $-0.143 * * *$ \\
\hline & $(0.034)$ & $(0.034)$ & $(0.030)$ & $(0.035)$ \\
\hline \multirow[t]{2}{*}{ Portugal } & $-0.328 * * *$ & $-0.355 * * *$ & $-0.449 * * *$ & $-0.483 * * *$ \\
\hline & $(0.030)$ & $(0.034)$ & $(0.033)$ & $(0.031)$ \\
\hline \multirow[t]{2}{*}{ Russian Federation } & $-0.239 * * *$ & $-0.261 * * *$ & $-0.408 * * *$ & $-0.296 * * *$ \\
\hline & $(0.036)$ & $(0.036)$ & $(0.030)$ & $(0.034)$ \\
\hline \multirow[t]{2}{*}{ Sweden } & $-0.577 * * *$ & $-0.625^{* * * *}$ & $-0.563 * * *$ & $-0.481 * * *$ \\
\hline & $(0.041)$ & $(0.044)$ & $(0.037)$ & $(0.042)$ \\
\hline \multirow[t]{2}{*}{ Slovenia } & $-0.598 * * *$ & $-0.641 * * *$ & $-0.737 * * *$ & $-0.624 * * *$ \\
\hline & $(0.034)$ & $(0.037)$ & $(0.030)$ & $(0.035)$ \\
\hline \multirow[t]{2}{*}{ Slovakia } & $-0.260 * * *$ & $-0.284 * * *$ & $-0.307 * * *$ & $-0.287 * * *$ \\
\hline & $(0.017)$ & $(0.018)$ & $(0.015)$ & $(0.022)$ \\
\hline \multirow[t]{2}{*}{ Ukraine } & $0.433 * * *$ & $0.395 * * *$ & $0.158 * *$ & 0.112 \\
\hline & $(0.062)$ & $(0.060)$ & $(0.077)$ & $(0.076)$ \\
\hline \multirow[t]{2}{*}{ Kosovo } & $-0.183 * * *$ & $-0.210 * * *$ & $-0.158 * * *$ & -0.003 \\
\hline & $(0.034)$ & $(0.035)$ & $(0.040)$ & $(0.042)$ \\
\hline Observations & 105,298 & 105,298 & 104,485 & 92,563 \\
\hline R-Squared & 0.094 & 0.096 & 0.172 & 0.177 \\
\hline
\end{tabular}

Country coefficients are those of the corresponding estimates of Table 2. Albania is the omitted benchmark

$M S$ marital status levels also taken into account, $S H$ self-health levels also taken into account, $S M$ social meeting levels also taken into account, $L R$ placement on left right scale also taken into account. Sample survival indicates the marginal effects of the covariates on the survival across waves. Clustered (for country) standard errors in parentheses

${ }^{* * *} p<0.01 ; * * p<0.05, * p<0.1$

Unfortunately, we cannot replicate composite psychological health indexes used in the recent literature since we do not have the GHQ questions of the BHPS used by Gardner and Oswald (2007) in the European Social Survey. We, however, create a GHQ-like index using similar questions in the ESS. The criteria we use are mainly three: (i) selection of questions concerning personal mood; (ii) exclusion of questions related to personal mood within last week to avoid dependence on short-term events as in the depression question; (iii) exclusion of questions concerning working condition mood in order to avoid circumstances that exclude part of the sample (i.e. retired, unemployed) from the analysis.

The selected questions are. 
1. Always optimistic about my future

2. In general feel very positive about myself

3. Hard to be hopeful about the future of the world

4. Feel accomplishment from what I do

5. Seldom time to do things I really enjoy

6. Little chance to show how capable I am

7. Feel what I do in life is valuable and worthwhile

8. On the whole life is close to how I would like it to be

9. At times I feel as if I am a failure

10. Free to decide how to live my life

In each of the ten questions respondents can choose among six possible answers (Agree strongly, Agree, Neither agree nor disagree, Disagree, Disagree strongly) plus three options (Refusal, Don't know, No answer) that we set to missing values. All questions are rescaled so that 6 indicates the answer closest to, while 1 the answer most distant from depression. The index potentially ranges from 10 to 60 but the highest value we observe is 54. Correlation with our short-term depression question is quite strong (0.38) thereby supporting the hypothesis that the latter is a good proxy of long-term depression. We estimate specifications of Table 3 with the new dependent variable and find that signs and significance of the main regressors are all confirmed (Table 5). Overall goodness of fit is higher ( $\mathrm{R}$ squared 0.22 ) while the addition of the three income related variables (level of income, subjective evaluation whether income is enough to cope with living needs and high importance of comparing with other people income) increases by $15 \%$ goodness of fit (in line with findings of the weight of monetary factors in estimates with the short-term depression dependent variable). Country effects are shown in Table 6.

\subsection{Robustness check on endogeneity}

As is well known the estimated nexus between regressors and the dependent variable does not necessarily imply direct causality due to endogeneity concerns.

When the dependent variable is something related to subjective wellbeing such as depression it is quite difficult to find valid instruments (i.e. instruments not affecting directly subjective wellbeing).

The difficulty lies as well on the fact that our paper is an exploratory analysis that focuses not just on a single variable but on the pattern of several drivers. This is a further obstacle to find a relevant and valid instrument for each of them.

We, however, perform a robustness check focusing on one of the two variables where (as emphasized by the referee) the suspicion of endogeneity is stronger (marital status). It may well be in fact that idiosyncratic personality traits (extroversion, proactivity, resilience among others) affect both the marital status regressors and the dependent variable. In order to identify a parsimonious specification limiting the number of selected exclusion restrictions we create a $(0 / 1)$ married status dummy resuming information we have from estimate findings where all other variables have a positive and significant effect on depression with respect to 
Table 5 The determinants of GHQ

\begin{tabular}{|c|c|c|c|c|}
\hline \multirow[t]{2}{*}{ Variables } & (1) & (2) & (3) & $(4)$ \\
\hline & Base & Base + MS & Base $+\mathrm{SH}+\mathrm{SM}$ & $\mathrm{Base}+\mathrm{SH}+\mathrm{SM}+\mathrm{LR}$ \\
\hline Male & $\begin{array}{l}-0.465^{* * *} \\
(0.070)\end{array}$ & $\begin{array}{l}-0.460 * * * \\
(0.063)\end{array}$ & $\begin{array}{l}-0.369 * * * \\
(0.063)\end{array}$ & $\begin{array}{l}-0.329 * * * \\
(0.071)\end{array}$ \\
\hline \multicolumn{5}{|l|}{ Age class } \\
\hline $0-19$ & $\begin{array}{l}-0.340 \\
(0.310)\end{array}$ & $\begin{array}{l}-0.793 * * \\
(0.301)\end{array}$ & $\begin{array}{l}0.609 * * \\
(0.241)\end{array}$ & $\begin{array}{l}0.807 * * * \\
(0.229)\end{array}$ \\
\hline $20-29$ & $\begin{array}{l}-0.078 \\
(0.159)\end{array}$ & $\begin{array}{l}-0.368 * * * \\
(0.121)\end{array}$ & $\begin{array}{l}0.652 * * * \\
(0.101)\end{array}$ & $\begin{array}{l}0.390 * * * \\
(0.106)\end{array}$ \\
\hline $30-39$ & $\begin{array}{l}0.454 * * * \\
(0.146)\end{array}$ & $\begin{array}{l}0.344 * * \\
(0.134)\end{array}$ & $\begin{array}{l}0.968 * * * \\
(0.133)\end{array}$ & $\begin{array}{l}0.725^{* * *} \\
(0.149)\end{array}$ \\
\hline $40-49$ & $\begin{array}{l}0.544 * * * \\
(0.144)\end{array}$ & $\begin{array}{l}0.489 * * * \\
(0.136)\end{array}$ & $\begin{array}{l}0.855^{* * * *} \\
(0.120)\end{array}$ & $\begin{array}{l}0.556^{* * *} \\
(0.108)\end{array}$ \\
\hline $50-59$ & $\begin{array}{l}0.634 * * * \\
(0.094)\end{array}$ & $\begin{array}{l}0.657 * * * \\
(0.090)\end{array}$ & $\begin{array}{l}0.636 * * * \\
(0.083)\end{array}$ & $\begin{array}{l}0.447 * * * \\
(0.081)\end{array}$ \\
\hline $60-69$ & $\begin{array}{l}-0.279 * * \\
(0.133)\end{array}$ & $\begin{array}{l}-0.197 \\
(0.135)\end{array}$ & $\begin{array}{l}-0.300 * * \\
(0.115)\end{array}$ & $\begin{array}{l}-0.356^{* * * *} \\
(0.119)\end{array}$ \\
\hline $80-89$ & $\begin{array}{l}-0.210 \\
(0.164)\end{array}$ & $\begin{array}{l}-0.199 \\
(0.148)\end{array}$ & $\begin{array}{l}-0.636^{* * * *} \\
(0.128)\end{array}$ & $\begin{array}{l}-0.368 * * \\
(0.140)\end{array}$ \\
\hline $90+$ & $\begin{array}{l}0.540 \\
(0.529)\end{array}$ & $\begin{array}{l}0.501 \\
(0.507)\end{array}$ & $\begin{array}{l}0.556 \\
(0.501)\end{array}$ & $\begin{array}{l}0.588 \\
(0.346)\end{array}$ \\
\hline \multicolumn{5}{|c|}{ Household's income } \\
\hline 2 & $\begin{array}{l}-1.597 * * * \\
(0.323)\end{array}$ & $\begin{array}{l}-1.545^{* * *} \\
(0.328)\end{array}$ & $\begin{array}{l}-1.294 * * * \\
(0.193)\end{array}$ & $\begin{array}{l}-0.516^{*} \\
(0.256)\end{array}$ \\
\hline 3 & $\begin{array}{l}-2.562 * * * \\
(0.479)\end{array}$ & $\begin{array}{l}-2.497 * * * \\
(0.482)\end{array}$ & $\begin{array}{l}-2.012 * * * \\
(0.301)\end{array}$ & $\begin{array}{l}-0.902 * * * \\
(0.173)\end{array}$ \\
\hline 4 & $\begin{array}{l}-3.067 * * * \\
(0.452)\end{array}$ & $\begin{array}{l}-2.994 * * * \\
(0.449)\end{array}$ & $\begin{array}{l}-2.242^{* * *} \\
(0.295)\end{array}$ & $\begin{array}{l}-0.826^{* * *} \\
(0.199)\end{array}$ \\
\hline 5 & $\begin{array}{l}-3.521 * * * \\
(0.460)\end{array}$ & $\begin{array}{l}-3.427 * * * \\
(0.456)\end{array}$ & $\begin{array}{l}-2.518^{* * *} \\
(0.308)\end{array}$ & $\begin{array}{l}-0.833^{* * *} \\
(0.219)\end{array}$ \\
\hline 6 & $\begin{array}{l}-3.979 * * * \\
(0.456)\end{array}$ & $\begin{array}{l}-3.864 * * * \\
(0.453)\end{array}$ & $\begin{array}{l}-2.809^{* * * *} \\
(0.321)\end{array}$ & $\begin{array}{l}-0.954 * * * \\
(0.205)\end{array}$ \\
\hline 7 & $\begin{array}{l}-4.186^{* * *} \\
(0.452)\end{array}$ & $\begin{array}{l}-4.032 * * * \\
(0.449)\end{array}$ & $\begin{array}{l}-2.819 * * * \\
(0.322)\end{array}$ & $\begin{array}{l}-0.781 * * * \\
(0.181)\end{array}$ \\
\hline 8 & $\begin{array}{l}-4.474 * * * \\
(0.453)\end{array}$ & $\begin{array}{l}-4.317^{* * * *} \\
(0.459)\end{array}$ & $\begin{array}{l}-3.045^{* * * *} \\
(0.324)\end{array}$ & $\begin{array}{l}-0.876^{* * *} \\
(0.206)\end{array}$ \\
\hline 9 & $\begin{array}{l}-4.771 * * * \\
(0.449)\end{array}$ & $\begin{array}{l}-4.598 * * * \\
(0.455)\end{array}$ & $\begin{array}{l}-3.193 * * * \\
(0.319)\end{array}$ & $\begin{array}{l}-0.821 * * * \\
(0.193)\end{array}$ \\
\hline 10 & $\begin{array}{l}-5.335^{* * *} \\
(0.491)\end{array}$ & $\begin{array}{l}-5.153^{* * *} \\
(0.502)\end{array}$ & $\begin{array}{l}-3.666^{* * * *} \\
(0.378)\end{array}$ & $\begin{array}{l}-1.102 * * * \\
(0.239)\end{array}$ \\
\hline Household size & $\begin{array}{l}0.039 \\
(0.038)\end{array}$ & $\begin{array}{l}0.110 * * \\
(0.039)\end{array}$ & $\begin{array}{l}0.124 * * * \\
(0.034)\end{array}$ & $\begin{array}{l}0.039 \\
(0.036)\end{array}$ \\
\hline
\end{tabular}


Table 5 (continued)

\begin{tabular}{|c|c|c|c|c|}
\hline \multirow[t]{2}{*}{ Variables } & (1) & (2) & (3) & (4) \\
\hline & Base & Base + MS & Base $+\mathrm{SH}+\mathrm{SM}$ & $\mathrm{Base}+\mathrm{SH}+\mathrm{SM}+\mathrm{LR}$ \\
\hline \multicolumn{5}{|l|}{ Education status } \\
\hline No or unfinished & $\begin{array}{l}-2.089 * * * \\
(0.297)\end{array}$ & $\begin{array}{l}-2.159 * * * \\
(0.290)\end{array}$ & $\begin{array}{l}-1.865 * * * \\
(0.245)\end{array}$ & $\begin{array}{l}-1.883 * * * \\
(0.215)\end{array}$ \\
\hline Primary & $\begin{array}{l}1.134 * * \\
(0.445)\end{array}$ & $\begin{array}{l}1.184 * * \\
(0.427)\end{array}$ & $\begin{array}{l}0.480 \\
(0.384)\end{array}$ & $\begin{array}{l}-0.082 \\
(0.334)\end{array}$ \\
\hline Lower Secondary & $\begin{array}{l}1.324 * * * \\
(0.236)\end{array}$ & $\begin{array}{l}1.339 * * * \\
(0.226)\end{array}$ & $\begin{array}{l}0.954 * * * \\
(0.189)\end{array}$ & $\begin{array}{l}0.631 * * * \\
(0.160)\end{array}$ \\
\hline Upper Secondary & $\begin{array}{l}0.659 * * * \\
(0.210)\end{array}$ & $\begin{array}{l}0.690 * * * \\
(0.206)\end{array}$ & $\begin{array}{l}0.395 * * \\
(0.170)\end{array}$ & $\begin{array}{l}0.216 \\
(0.150)\end{array}$ \\
\hline Post-Secondary & $\begin{array}{l}0.624 * * * \\
(0.194)\end{array}$ & $\begin{array}{l}0.635 * * * \\
(0.191)\end{array}$ & $\begin{array}{l}0.490 * * \\
(0.186)\end{array}$ & $\begin{array}{l}0.388 * * \\
(0.176)\end{array}$ \\
\hline First Level Tertiary & $\begin{array}{l}0.373 \\
(0.243)\end{array}$ & $\begin{array}{l}0.393 \\
(0.241)\end{array}$ & $\begin{array}{l}0.319 \\
(0.215)\end{array}$ & $\begin{array}{l}0.257 \\
(0.236)\end{array}$ \\
\hline Second Level Tertiary & $\begin{array}{l}0.132 \\
(0.258)\end{array}$ & $\begin{array}{l}0.146 \\
(0.260)\end{array}$ & $\begin{array}{l}0.210 \\
(0.203)\end{array}$ & $\begin{array}{l}0.132 \\
(0.172)\end{array}$ \\
\hline \multicolumn{5}{|l|}{ Month of interview } \\
\hline February & $\begin{array}{l}-0.017 \\
(0.196)\end{array}$ & $\begin{array}{l}-0.024 \\
(0.196)\end{array}$ & $\begin{array}{l}-0.049 \\
(0.164)\end{array}$ & $\begin{array}{l}-0.075 \\
(0.167)\end{array}$ \\
\hline March & $\begin{array}{l}0.241 \\
(0.372)\end{array}$ & $\begin{array}{l}0.248 \\
(0.369)\end{array}$ & $\begin{array}{l}0.206 \\
(0.378)\end{array}$ & $\begin{array}{l}0.320 \\
(0.408)\end{array}$ \\
\hline April & $\begin{array}{l}-0.130 \\
(0.175)\end{array}$ & $\begin{array}{l}-0.151 \\
(0.179)\end{array}$ & $\begin{array}{l}-0.161 \\
(0.176)\end{array}$ & $\begin{array}{l}0.005 \\
(0.167)\end{array}$ \\
\hline May & $\begin{array}{l}-0.525^{* * * *} \\
(0.133)\end{array}$ & $\begin{array}{l}-0.520 * * * \\
(0.132)\end{array}$ & $\begin{array}{l}-0.106 \\
(0.118)\end{array}$ & $\begin{array}{l}-0.489 * * * \\
(0.108)\end{array}$ \\
\hline June & $\begin{array}{l}-0.457 * * \\
(0.189)\end{array}$ & $\begin{array}{l}-0.458 * * \\
(0.176)\end{array}$ & $\begin{array}{l}-0.331 \\
(0.193)\end{array}$ & $\begin{array}{l}0.097 \\
(0.203)\end{array}$ \\
\hline July & $\begin{array}{l}-0.332 \\
(0.486)\end{array}$ & $\begin{array}{l}-0.283 \\
(0.485)\end{array}$ & $\begin{array}{l}-0.270 \\
(0.451)\end{array}$ & $\begin{array}{l}-0.329 \\
(0.397)\end{array}$ \\
\hline August & $\begin{array}{l}-0.297 \\
(0.386)\end{array}$ & $\begin{array}{l}-0.267 \\
(0.391)\end{array}$ & $\begin{array}{l}-0.264 \\
(0.327)\end{array}$ & $\begin{array}{l}-0.020 \\
(0.317)\end{array}$ \\
\hline September & $\begin{array}{l}-0.078 \\
(0.191)\end{array}$ & $\begin{array}{l}-0.056 \\
(0.190)\end{array}$ & $\begin{array}{l}-0.091 \\
(0.198)\end{array}$ & $\begin{array}{l}-0.011 \\
(0.179)\end{array}$ \\
\hline October & $\begin{array}{l}-0.113 \\
(0.153)\end{array}$ & $\begin{array}{l}-0.099 \\
(0.152)\end{array}$ & $\begin{array}{l}-0.081 \\
(0.141)\end{array}$ & $\begin{array}{l}0.027 \\
(0.135)\end{array}$ \\
\hline November & $\begin{array}{l}0.052 \\
(0.150)\end{array}$ & $\begin{array}{l}0.053 \\
(0.148)\end{array}$ & $\begin{array}{l}0.069 \\
(0.141)\end{array}$ & $\begin{array}{l}0.129 \\
(0.127)\end{array}$ \\
\hline December & $\begin{array}{l}0.020 \\
(0.165)\end{array}$ & $\begin{array}{l}0.016 \\
(0.161)\end{array}$ & $\begin{array}{l}0.000 \\
(0.167)\end{array}$ & $\begin{array}{l}0.085 \\
(0.153)\end{array}$ \\
\hline \multicolumn{5}{|l|}{ Marital status } \\
\hline Registered partner & & $\begin{array}{l}0.946 * * * \\
(0.175)\end{array}$ & $\begin{array}{l}0.965 * * * \\
(0.176)\end{array}$ & $\begin{array}{l}0.727 * * * \\
(0.175)\end{array}$ \\
\hline
\end{tabular}


Table 5 (continued)

\begin{tabular}{|c|c|c|c|c|}
\hline \multirow[t]{2}{*}{ Variables } & (1) & (2) & (3) & (4) \\
\hline & Base & Base + MS & Base $+\mathrm{SH}+\mathrm{SM}$ & Base $+\mathrm{SH}+\mathrm{SM}+\mathrm{LR}$ \\
\hline \multicolumn{2}{|l|}{ Separated } & - & - & - \\
\hline \multirow[t]{2}{*}{ Divorced } & & $0.458 * *$ & $0.578 * * *$ & 0.288 \\
\hline & & $(0.166)$ & $(0.159)$ & $(0.175)$ \\
\hline \multirow[t]{2}{*}{ Widowed } & & $0.418 * *$ & 0.220 & -0.022 \\
\hline & & $(0.188)$ & $(0.177)$ & $(0.155)$ \\
\hline \multirow[t]{2}{*}{ Never married } & & $0.646^{* * * *}$ & $0.862 * * *$ & $0.732 * * *$ \\
\hline & & $(0.104)$ & $(0.090)$ & $(0.091)$ \\
\hline \multicolumn{5}{|l|}{ Self-assessed health } \\
\hline \multirow[t]{2}{*}{ Good } & & & $1.672 * * *$ & $1.602 * * *$ \\
\hline & & & $(0.096)$ & $(0.085)$ \\
\hline \multirow[t]{2}{*}{ Fair } & & & $3.383 * * *$ & $3.097 * * *$ \\
\hline & & & $(0.112)$ & $(0.106)$ \\
\hline \multirow[t]{2}{*}{ Bad } & & & $5.386 * * *$ & $4.686 * * *$ \\
\hline & & & $(0.235)$ & $(0.215)$ \\
\hline \multirow[t]{2}{*}{ Very Bad } & & & $7.107 * * *$ & $6.011 * * *$ \\
\hline & & & $(0.287)$ & $(0.349)$ \\
\hline \multicolumn{5}{|l|}{ Social meeting } \\
\hline \multirow[t]{2}{*}{ Less than once a month } & & & $-1.081 * * *$ & $-0.963 * * *$ \\
\hline & & & $(0.347)$ & $(0.334)$ \\
\hline \multirow[t]{2}{*}{ Once a month } & & & $-1.864 * * *$ & $-1.553 * * *$ \\
\hline & & & $(0.314)$ & (0.309) \\
\hline \multirow[t]{2}{*}{ Several times a month } & & & $-2.449 * * *$ & $-2.135 * * *$ \\
\hline & & & $(0.313)$ & $(0.319)$ \\
\hline \multirow[t]{2}{*}{ Once a week } & & & $-2.415^{* * * *}$ & $-2.166^{* * * *}$ \\
\hline & & & $(0.315)$ & $(0.328)$ \\
\hline \multirow[t]{2}{*}{ Several times a week } & & & $-3.097 * * *$ & $-2.745 * * *$ \\
\hline & & & $(0.357)$ & $(0.347)$ \\
\hline \multirow[t]{2}{*}{ Every day } & & & $-3.436^{* * * *}$ & $-3.149 * * *$ \\
\hline & & & $(0.310)$ & $(0.312)$ \\
\hline \multicolumn{5}{|c|}{ Placement on left right scale } \\
\hline \multirow[t]{2}{*}{1} & & & & $0.487 * *$ \\
\hline & & & & $(0.232)$ \\
\hline \multirow[t]{2}{*}{2} & & & & $0.890 * * *$ \\
\hline & & & & $(0.191)$ \\
\hline \multirow[t]{2}{*}{3} & & & & $0.620 * * *$ \\
\hline & & & & $(0.208)$ \\
\hline \multirow[t]{2}{*}{4} & & & & $0.451 * *$ \\
\hline & & & & $(0.187)$ \\
\hline \multirow[t]{2}{*}{5} & & & & 0.332 \\
\hline & & & & $(0.205)$ \\
\hline 6 & & & & 0.378 \\
\hline
\end{tabular}


Table 5 (continued)

\begin{tabular}{|c|c|c|c|c|}
\hline \multirow[t]{2}{*}{ Variables } & \multirow{2}{*}{$\begin{array}{l}\text { (1) } \\
\text { Base }\end{array}$} & \multirow{2}{*}{$\begin{array}{l}\text { (2) } \\
\text { Base +MS }\end{array}$} & \multirow{2}{*}{$\begin{array}{l}\text { (3) } \\
\text { Base }+\mathrm{SH}+\mathrm{SM}\end{array}$} & \multirow{2}{*}{$\begin{array}{l}\text { (4) } \\
\text { Base }+\mathrm{SH}+\mathrm{SM}+\mathrm{LR}\end{array}$} \\
\hline & & & & \\
\hline & & & & $(0.224)$ \\
\hline \multirow[t]{2}{*}{7} & & & & 0.156 \\
\hline & & & & $(0.192)$ \\
\hline \multirow[t]{2}{*}{8} & & & & 0.144 \\
\hline & & & & $(0.229)$ \\
\hline \multirow[t]{2}{*}{9} & & & & -0.217 \\
\hline & & & & $(0.314)$ \\
\hline \multirow[t]{2}{*}{10} & & & & -0.261 \\
\hline & & & & $(0.265)$ \\
\hline \multicolumn{5}{|c|}{ Feeling about Household's income nowadays } \\
\hline \multirow[t]{2}{*}{ Copying on present income } & & & & $1.090 * * *$ \\
\hline & & & & $(0.093)$ \\
\hline \multirow[t]{2}{*}{ Difficult on present income } & & & & $2.630 * * *$ \\
\hline & & & & $(0.165)$ \\
\hline \multirow{2}{*}{\multicolumn{2}{|c|}{ Very difficult on present income }} & & & $4.126^{* * *}$ \\
\hline & & & & $(0.368)$ \\
\hline Country $\times$ Wave Dummies & Yes & Yes & Yes & Yes \\
\hline Country dummies & Yes & Yes & Yes & Yes \\
\hline \multirow[t]{2}{*}{ Constant } & $28.379 * * *$ & $27.902 * * *$ & $27.076 * * *$ & $24.012 * * *$ \\
\hline & $(0.467)$ & $(0.507)$ & $(0.521)$ & $(0.476)$ \\
\hline Observations & 28,466 & 28,466 & 28,331 & 25,192 \\
\hline R-Squared & 0.117 & 0.119 & 0.221 & 0.244 \\
\hline
\end{tabular}

Omitted benchmarks: age class between 70 and 79; first (lowest income) class of the household's net income; "Upper Tertiary" class for education status; Month of "February" for Month of interview; "Married" class for marital status; "Very Good" class of self-assessed health; "Never" class of social meeting; the 0 (extreme left) class of placement in the political opinion left-right scale; "Living Comfortably on present income" in the Feeling about Household's income question, Albania for country dummies

$M S$ marital status levels also taken into account, $S H$ self-health levels also taken into account, $S M$ social meeting levels also taken into account, $L R$ placement on left right scale also taken into account. Sample survival indicates the marginal effects of the covariates on the survival across waves. Clustered (for country) standard errors in parentheses

${ }^{* * *} p<0.01, * * p<0.05, * p<0.1$

the married status benchmark. We perform a probit IV estimate using the depression dependent variable and an OLS estimate using the GHQ-like dependent variable using as instrument the average respondent's country/age/gender/Eisced education level share of married for the married dummy. Our hypothesis is that the instrument is relevant (the average share of married respondents of the same age cohort, gender and education level in the respondent country is correlated with the probability that the respondent gets married) and valid (this average does not directly affect depression of the respondent). Our first stage IV findings confirm 
Table 6 Country effects

\begin{tabular}{|c|c|c|c|c|}
\hline \multirow[t]{2}{*}{ Variables } & (1) & (2) & (3) & (4) \\
\hline & Base & Base + MS & Base $+\mathrm{SH}+\mathrm{SM}$ & $\mathrm{Base}+\mathrm{SH}+\mathrm{SM}+\mathrm{LR}$ \\
\hline \multicolumn{5}{|l|}{ Country } \\
\hline Belgium & $\begin{array}{l}-0.595^{* * * *} \\
(0.159)\end{array}$ & $\begin{array}{l}-0.658^{* * * *} \\
(0.157)\end{array}$ & $\begin{array}{l}-0.415^{* *} \\
(0.153)\end{array}$ & $\begin{array}{l}-0.321 * * \\
(0.141)\end{array}$ \\
\hline Bulgaria & $\begin{array}{l}0.603 * \\
(0.299)\end{array}$ & $\begin{array}{l}0.761 * * \\
(0.297)\end{array}$ & $\begin{array}{l}0.551 * * \\
(0.245)\end{array}$ & $\begin{array}{l}-0.311 \\
(0.255)\end{array}$ \\
\hline Switzerland & $\begin{array}{l}-1.586^{* * * *} \\
(0.214)\end{array}$ & $\begin{array}{l}-1.686^{* * * *} \\
(0.212)\end{array}$ & $\begin{array}{l}-1.103 * * * \\
(0.213)\end{array}$ & $\begin{array}{l}-1.247 * * * \\
(0.200)\end{array}$ \\
\hline Cyprus & $\begin{array}{l}0.793 * * * \\
(0.117)\end{array}$ & $\begin{array}{l}0.889 * * * \\
(0.118)\end{array}$ & $\begin{array}{l}0.629 * * * \\
(0.113)\end{array}$ & $\begin{array}{l}0.520 * * * \\
(0.114)\end{array}$ \\
\hline Germany & $\begin{array}{l}-0.783 * * * \\
(0.148)\end{array}$ & $\begin{array}{l}-0.841^{* * * *} \\
(0.145)\end{array}$ & $\begin{array}{l}-1.153 * * * \\
(0.135)\end{array}$ & $\begin{array}{l}-1.227 * * * \\
(0.135)\end{array}$ \\
\hline Denmark & $\begin{array}{l}-2.859 * * * \\
(0.193)\end{array}$ & $\begin{array}{l}-2.925^{* * * *} \\
(0.191)\end{array}$ & $\begin{array}{l}-2.380 * * * \\
(0.194)\end{array}$ & $\begin{array}{l}-1.955^{* * * *} \\
(0.193)\end{array}$ \\
\hline Spain & $\begin{array}{l}-1.278 * * * \\
(0.177)\end{array}$ & $\begin{array}{l}-1.343^{* * * *} \\
(0.173)\end{array}$ & $\begin{array}{l}-1.274 * * * \\
(0.161)\end{array}$ & $\begin{array}{l}-0.923 * * * \\
(0.155)\end{array}$ \\
\hline Finland & $\begin{array}{l}2.041 * * * \\
(0.119)\end{array}$ & $\begin{array}{l}2.072 * * * \\
(0.121)\end{array}$ & $\begin{array}{l}1.623 * * * \\
(0.114)\end{array}$ & $\begin{array}{l}1.529 * * * \\
(0.121)\end{array}$ \\
\hline France & $\begin{array}{l}0.483 * * * \\
(0.168)\end{array}$ & $\begin{array}{l}0.401 * * \\
(0.164)\end{array}$ & $\begin{array}{l}0.510 * * * \\
(0.157)\end{array}$ & $\begin{array}{l}0.658 * * * \\
(0.158)\end{array}$ \\
\hline United Kingdom & $\begin{array}{l}2.958 * * * \\
(0.115)\end{array}$ & $\begin{array}{l}2.946^{* * * *} \\
(0.117)\end{array}$ & $\begin{array}{l}2.738 * * * \\
(0.097)\end{array}$ & $\begin{array}{l}2.652 * * * \\
(0.088)\end{array}$ \\
\hline Ireland & $\begin{array}{l}0.937 * * * \\
(0.084)\end{array}$ & $\begin{array}{l}0.920 * * * \\
(0.083)\end{array}$ & $\begin{array}{l}0.747 * * * \\
(0.077)\end{array}$ & $\begin{array}{l}0.783 * * * \\
(0.078)\end{array}$ \\
\hline Latvia & $\begin{array}{l}0.938 * * \\
(0.401)\end{array}$ & $\begin{array}{l}0.898 * * \\
(0.404)\end{array}$ & $\begin{array}{l}0.524 \\
(0.343)\end{array}$ & $\begin{array}{l}0.432 \\
(0.322)\end{array}$ \\
\hline Netherlands & $\begin{array}{l}-1.245^{* * * *} \\
(0.175)\end{array}$ & $\begin{array}{l}-1.332^{* * * *} \\
(0.172)\end{array}$ & $\begin{array}{l}-1.032 * * * \\
(0.165)\end{array}$ & $\begin{array}{l}-0.761 * * * \\
(0.155)\end{array}$ \\
\hline Norway & $\begin{array}{l}-0.720 * * * \\
(0.209)\end{array}$ & $\begin{array}{l}-0.825^{* * * *} \\
(0.209)\end{array}$ & $\begin{array}{l}-0.454 * * \\
(0.209)\end{array}$ & $\begin{array}{l}-0.357 * \\
(0.197)\end{array}$ \\
\hline Poland & $\begin{array}{l}-0.659 * * * \\
(0.074)\end{array}$ & $\begin{array}{l}-0.662^{* * * *} \\
(0.071)\end{array}$ & $\begin{array}{l}-0.954 * * * \\
(0.070)\end{array}$ & $\begin{array}{l}-0.675^{* * * *} \\
(0.057)\end{array}$ \\
\hline Portugal & $\begin{array}{l}2.587 * * * \\
(0.166)\end{array}$ & $\begin{array}{l}2.704 * * * \\
(0.165)\end{array}$ & $\begin{array}{l}2.278 * * * \\
(0.161)\end{array}$ & $\begin{array}{l}1.941 * * * \\
(0.156)\end{array}$ \\
\hline Russian Federation & $\begin{array}{l}-0.873 * * * \\
(0.174)\end{array}$ & $\begin{array}{l}-0.828^{* * * *} \\
(0.176)\end{array}$ & $\begin{array}{l}-1.474 * * * \\
(0.115)\end{array}$ & $\begin{array}{l}-1.250 * * * \\
(0.097)\end{array}$ \\
\hline Sweden & $\begin{array}{l}1.894 * * * \\
(0.125)\end{array}$ & $\begin{array}{l}1.871^{* * * *} \\
(0.128)\end{array}$ & $\begin{array}{l}1.798 * * * \\
(0.117)\end{array}$ & $\begin{array}{l}2.035^{* * * *} \\
(0.112)\end{array}$ \\
\hline Slovenia & $\begin{array}{l}-1.202 * * * \\
(0.116)\end{array}$ & $\begin{array}{l}-1.307^{* * *} \\
(0.115)\end{array}$ & $\begin{array}{l}-1.731 * * * \\
(0.102)\end{array}$ & $\begin{array}{l}-0.945^{* * * *} \\
(0.104)\end{array}$ \\
\hline Observations & 28,466 & 28,466 & 28,331 & 25,192 \\
\hline R-Squared & 0.117 & 0.119 & 0.221 & 0.244 \\
\hline
\end{tabular}


Table 6 (continued)

Country coefficients are those of the corresponding estimates of Table 2. Austria is the omitted benchmark

$M S$ marital status levels also taken into account, $S H$ self-health levels also taken into account, $S M$ social meeting levels also taken into account, $L R$ placement on left right scale also taken into account. Sample survival indicates the marginal effects of the covariates on the survival across waves. Clustered (for country) standard errors in parentheses

${ }^{* * *} p<0.01,{ }^{* *} p<0.05, * p<0.1$

that the instrument is relevant while second stage findings show that the instrumented variable significantly affects depression (Table 7).

To test more directly the validity of our instrument we find that the latter is not significant when introduced in the main non-instrumented estimate supporting the hypothesis that it affects the dependent variable only through the instrumented regressor.

Table 7 IV estimates

\begin{tabular}{|c|c|c|}
\hline Variables & (1) & (2) \\
\hline & GHQ & Depression \\
\hline \multicolumn{3}{|l|}{ Second stage } \\
\hline Married marital status (instrumented) & $\begin{array}{l}-0.337^{* *} \\
(0.171)\end{array}$ & $\begin{array}{l}-0.199 * * * \\
(0.061)\end{array}$ \\
\hline \multicolumn{3}{|l|}{ First stage } \\
\hline $\begin{array}{l}\text { Average level of married people (same } \\
\text { age, country, gender and Eisced level) }\end{array}$ & $\begin{array}{l}0.809 * * * \\
(0.011)\end{array}$ & $\begin{array}{l}0.751 * * * \\
(0.006)\end{array}$ \\
\hline \multicolumn{3}{|l|}{ Falsification test } \\
\hline $\begin{array}{l}\text { Average level of married people (same } \\
\text { age, country, gender and Eisced level) }\end{array}$ & $\begin{array}{l}0.218 \\
(0.176)\end{array}$ & $\begin{array}{l}-0.093 * * \\
(0.044)\end{array}$ \\
\hline
\end{tabular}

Omitted benchmarks: age class between 70 and 79; first (lowest income) class of the household's net income; "Upper Tertiary" class for education status; Month of "January" for Month of interview; "Married" class for marital status; "Very Good" class of selfassessed health; "Never" class of social meeting; the 0 (extreme left) class of placement in the political opinion left-right scale; "Living Comfortably on present income" in the Feeling about Household's income question, Albania for country dummies

Column (1) shows estimates with GHQ as dependent variable; column (2) shows estimates with depression as dependent variable. Sample survival indicates the marginal effects of the covariates on the survival across waves. Clustered (for country) standard errors in parentheses

${ }^{* * *} p<0.01, * * p<0.05, * p<0.1$ 


\section{Conclusions}

The surprising and unexpected inversion in the falling worldwide mortality trends for the white non-Hispanic middle age class in the US (also defined as the "despair death crisis") has stimulated economists, social scientists and policymakers to focus their attention not only on the right tail of the happiness distribution.

With the goal of providing useful information to prevent a despair death crisis in Europe we investigate drivers of depression (a condition which may lead in the worst cases to despair death) in European countries. A first important result is that factors correlated with depression are not just the inverse of those correlated with the probability of being satisfied about life. The most important paradox, consistently with the previous literature, concerns the gender effect with female gender having a higher likelihood than male gender to be both depressed or very happy.

A second important finding is that non-monetary factors play an important role accounting for not less than $80 \%$ of the explained variability of depression in our sample.

Depression is a worldwide phenomenon with deep social and economic costs ranging from productivity losses to increased health expenditure. This is why policy implications from the analysis of their drivers are of foremost importance. An important caveat before discussing them concerns the limits of our research, as of many other studies, in verifying whether the observed significant correlations correspond or not to direct causality links. In our robustness checks we, however, show that for one of the two main endogeneity candidates (marital status) we identify a relevant and valid instrument that suggests that the estimated nexus hides causality. Our cautious preliminary disclaimer when discussing policy implications remains, however, that they are valid conditionally to the previous check that all our significant associations of variables match with corresponding direct causality links.

Conditionally to the validity of this hypothesis a policy suggestion that would stem from our analysis is that the "poverty of sense of life illness" leading to depression in EES countries cannot be cured only with redistribution policies based on income transfers. Even though income class and (un)satisfaction with income play an important role, a fundamental part of the illness is determined by non-monetary factors related to education, health and relational life.

Investment in health, education and in policies aimed at fostering relational life (work-life balance) should therefore play a crucial role in preventing the occurrence of a similar crisis in Europe. Cultural developments that de-emphasize positional competition and emphasize the value of human beings beyond their economic and social performance could also play an important role.

On the health side universal NHS access, prevention and healthy lifestyle campaigns and, in presence of pandemics, proper vaccination policies are the most important strategies coupled with active ageing strategies that significantly contribute to increase quality of life and life expectancy of the elders.

Beyond public investment in education, policies for lifelong learning and against school dropout contributing, respectively, to active ageing and the 
reduction of youth NEET (neither study nor work) rates are as well fundamental. From this point of view the school dropout problem can be tackled by stimulating student desire to learn and to pursue a professional path. In this respect school experiences can be crucial if teaching is not limited to face-to-face transmission of concepts from the teacher to students while involving lab activities where students can express their creativity and experience.

All these initiatives should be useful to stimulate active and generative living that contributes to enrich sense of life and is the main antidote against depression.

\section{Appendix: Tables and graphs for average marginal effects}

Tables 8, 9, 10, 11, 12, 13, 14, 15, 16, and 17; Figs. 2, 3, 4, 5, 6, 7, 8, 9, 10, 11.

Table 8 The average marginal effects of the self-assessed health on Depression

\begin{tabular}{|c|c|c|c|c|}
\hline \multirow[t]{2}{*}{ Variables } & (1) & (2) & (3) & (4) \\
\hline & Base & Base + MS & Base $+\mathrm{SH}+\mathrm{SM}$ & $\mathrm{Base}+\mathrm{SH}+\mathrm{SM}+\mathrm{LR}$ \\
\hline \multicolumn{5}{|l|}{ Self-health } \\
\hline Good & 0 & 0 & $\begin{array}{l}0.015 * * * \\
(0.002)\end{array}$ & $\begin{array}{l}0.015 * * * \\
(0.002)\end{array}$ \\
\hline Fair & 0 & 0 & $\begin{array}{l}0.064 * * * \\
(0.003)\end{array}$ & $\begin{array}{l}0.057 * * * \\
(0.003)\end{array}$ \\
\hline $\mathrm{Bad}$ & 0 & 0 & $\begin{array}{l}0.186^{* * *} \\
(0.008)\end{array}$ & $\begin{array}{l}0.159 * * * \\
(0.007)\end{array}$ \\
\hline Very bad & 0 & 0 & $\begin{array}{l}0.347 * * * \\
(0.019)\end{array}$ & $\begin{array}{l}0.301 * * * \\
(0.020)\end{array}$ \\
\hline Observations & 105,298 & 105,298 & 104,485 & 92,563 \\
\hline R-Squared & 0.094 & 0.096 & 0.172 & 0.177 \\
\hline
\end{tabular}

The "very good" class of the self-health is the omitted benchmark. Sample survival indicates the marginal effects of the covariates on the survival across waves. Clustered (for country) standard errors in parentheses

$M S$ marital status levels also taken into account, $S H$ self-health levels also taken into account, $S M$ social meeting levels also taken into account. $L R$ placement on left right scale also taken into account

$* * * p<0.01, * * p<0.05, * p<0.1$ 


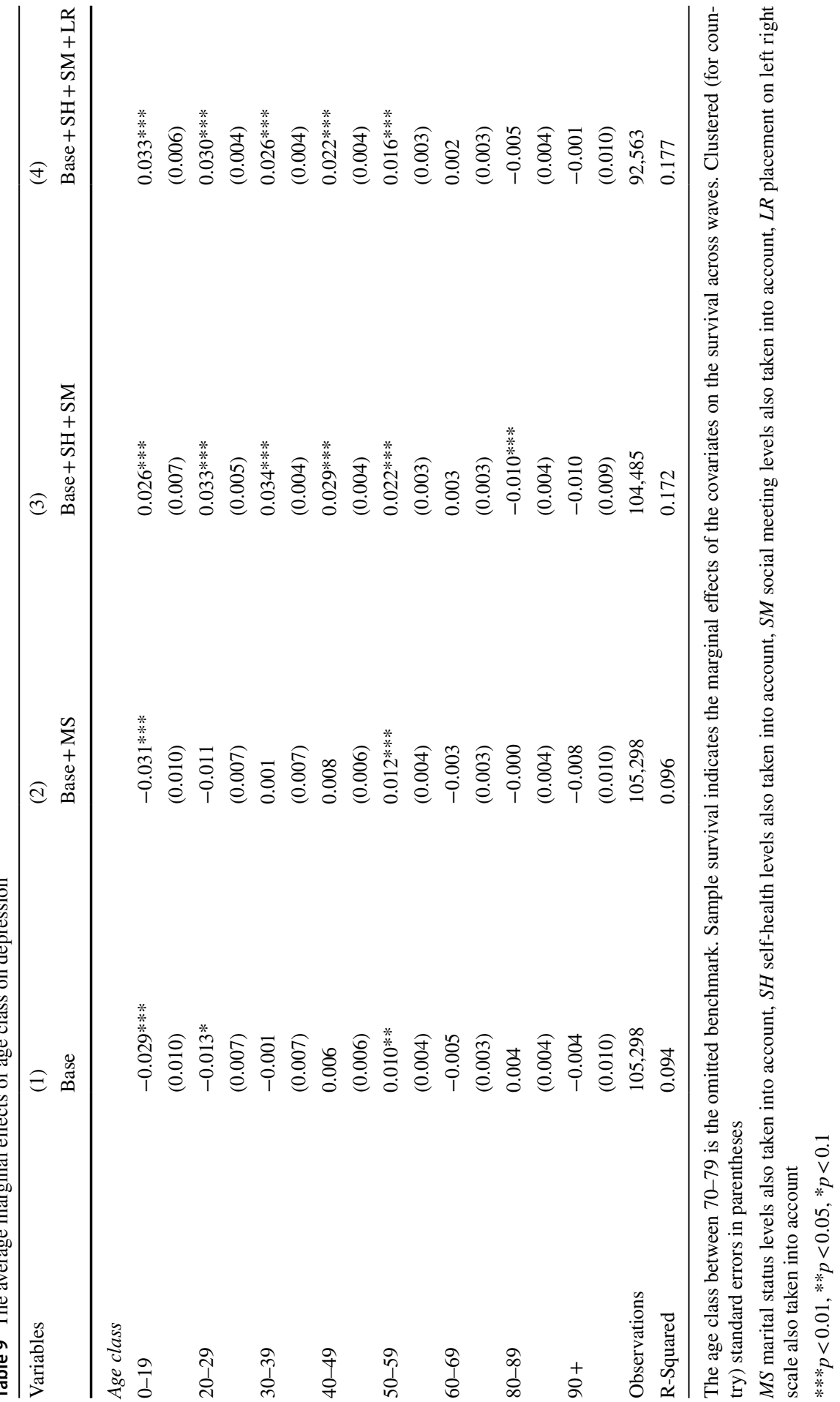




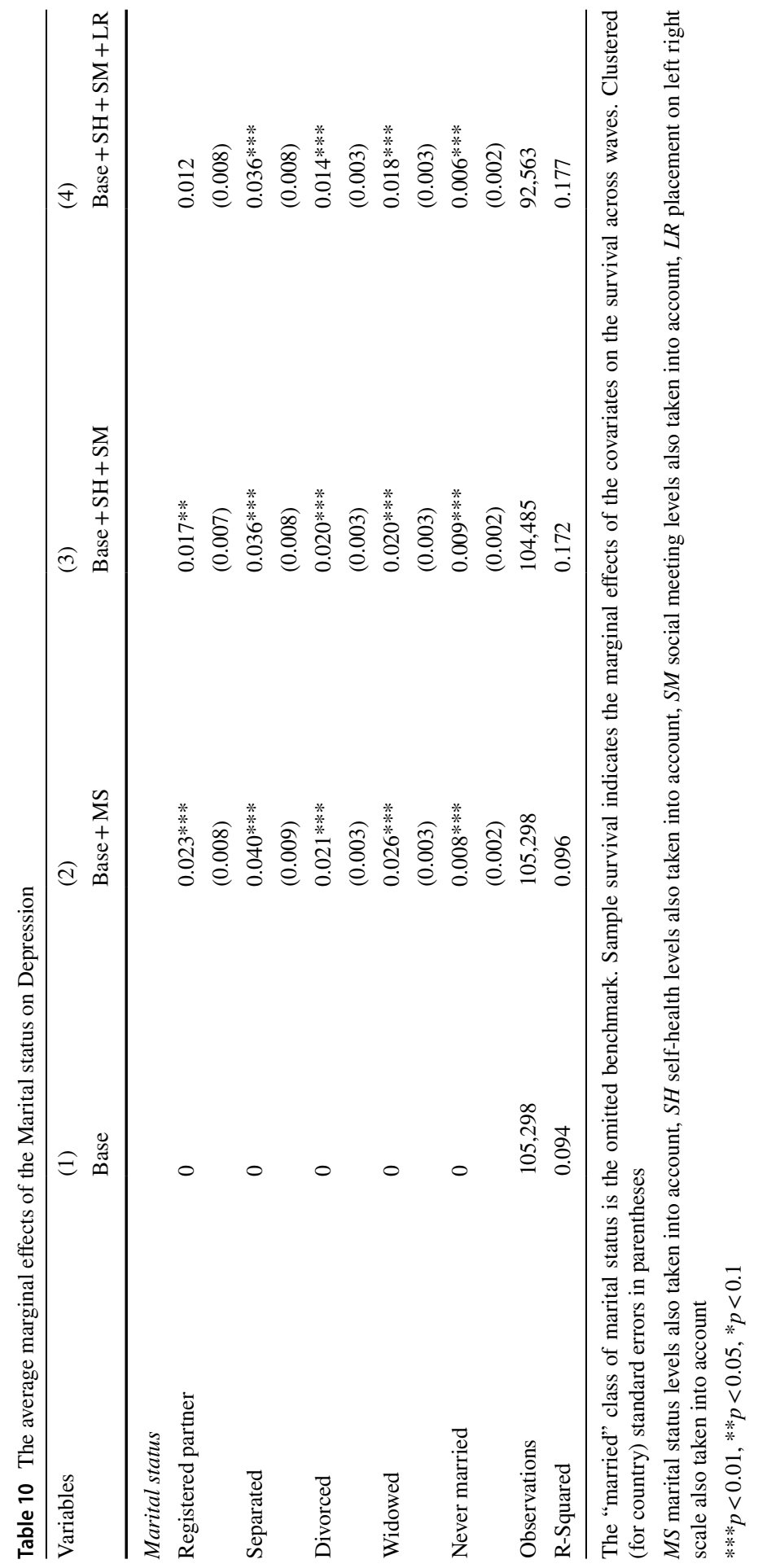




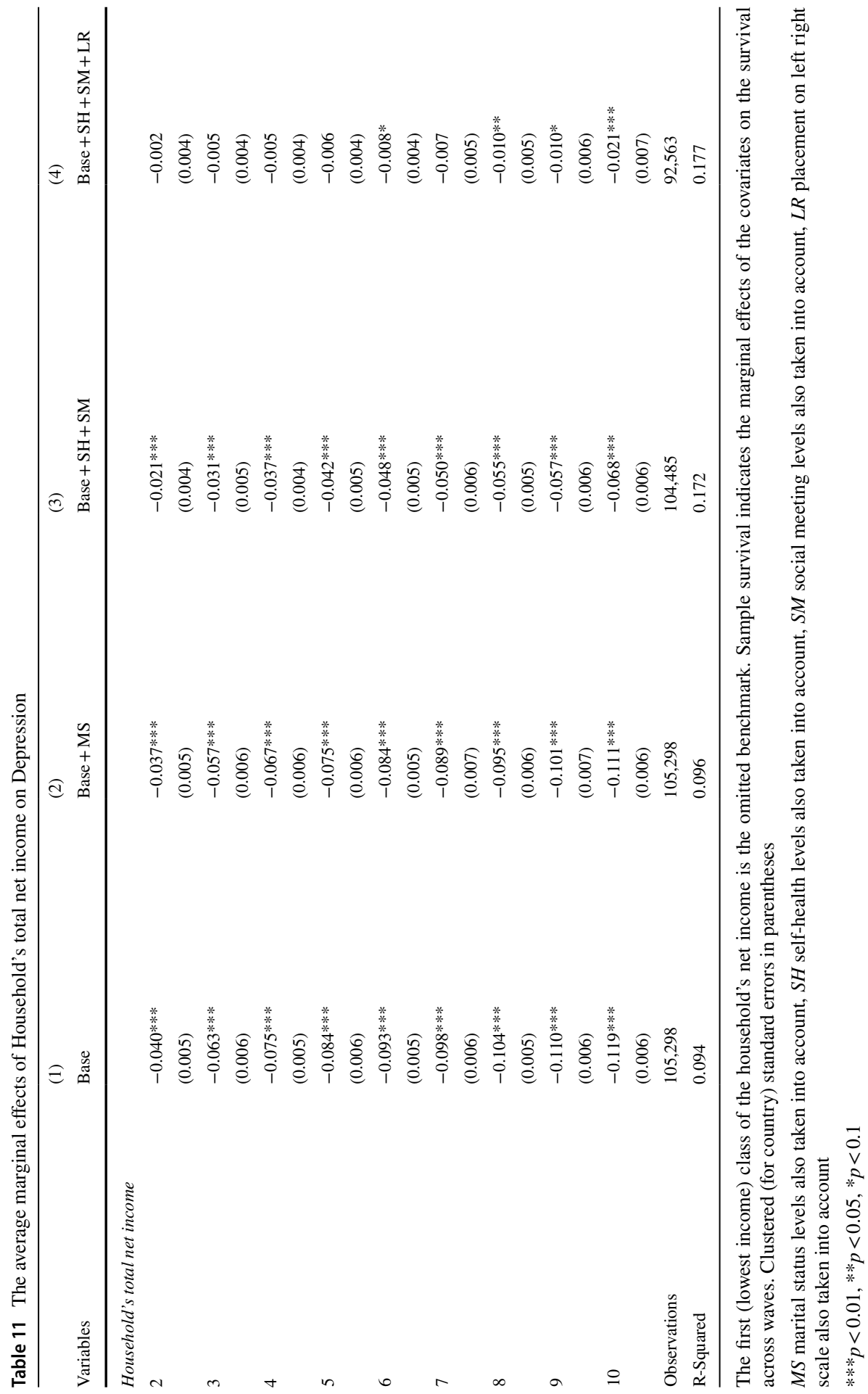




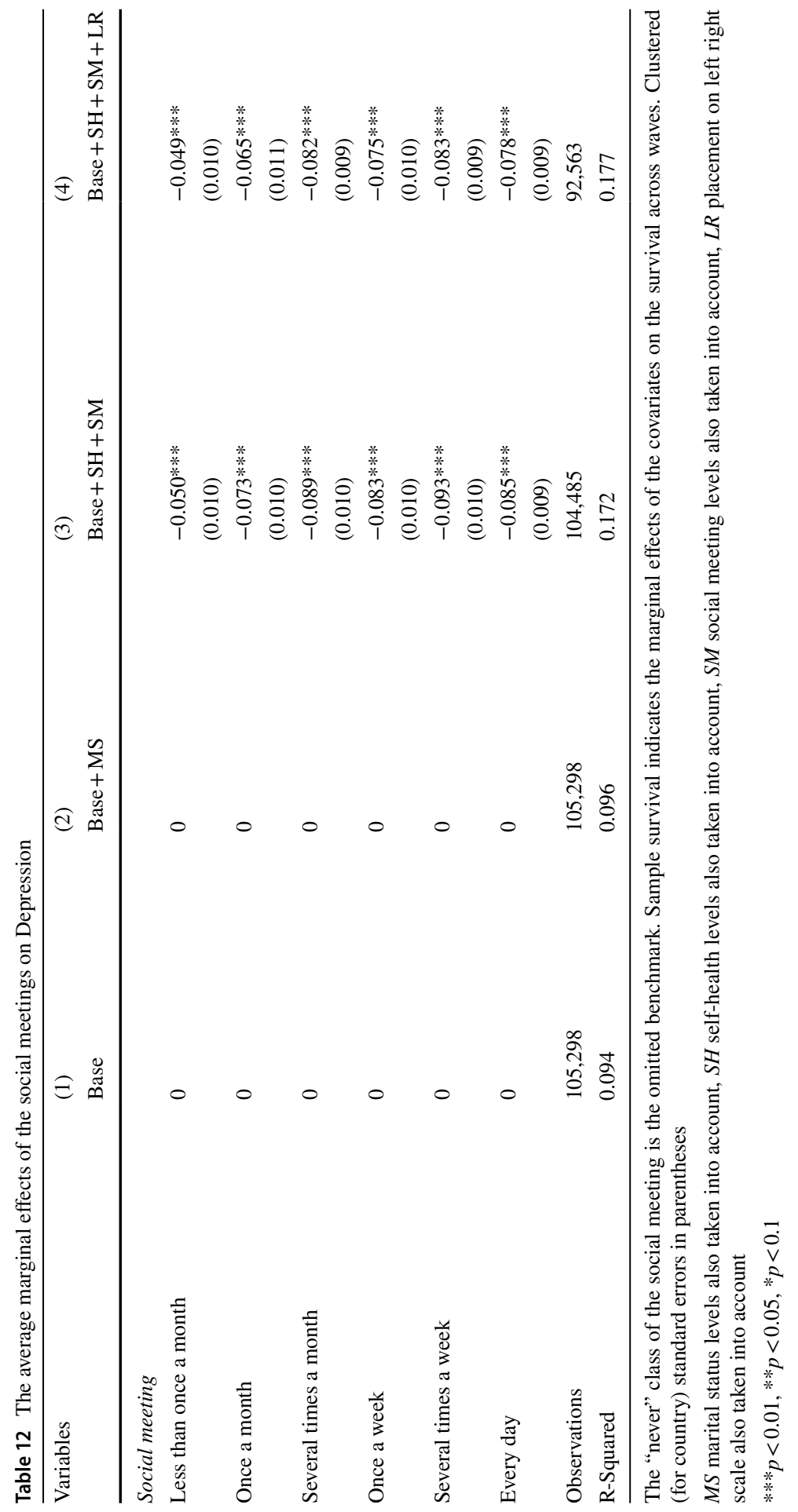


Table 13 The average marginal effects of Educational status on Depression

\begin{tabular}{|c|c|c|c|c|}
\hline Variables & $\begin{array}{l}(1) \\
\text { Base }\end{array}$ & $\begin{array}{l}(2) \\
\text { Base + MS }\end{array}$ & $\begin{array}{l}\text { (3) } \\
\text { Base }+\mathrm{SH}+\mathrm{SM}\end{array}$ & $\begin{array}{l}\text { (4) } \\
\text { Base }+\mathrm{SH}+\mathrm{SM}+\mathrm{LR}\end{array}$ \\
\hline \multicolumn{5}{|l|}{ Education status } \\
\hline No or unfinished & $\begin{array}{l}0.027 * * * \\
(0.004)\end{array}$ & $\begin{array}{l}0.028 * * * \\
(0.004)\end{array}$ & $\begin{array}{l}0.020 * * * \\
(0.004)\end{array}$ & $\begin{array}{l}0.016^{* * * *} \\
(0.003)\end{array}$ \\
\hline Lower secondary & $\begin{array}{l}0.053 * * * \\
(0.004)\end{array}$ & $\begin{array}{l}0.054 * * * \\
(0.004)\end{array}$ & $\begin{array}{l}0.028 * * * \\
(0.004)\end{array}$ & $\begin{array}{l}0.022 * * * \\
(0.004)\end{array}$ \\
\hline Upper secondary & $\begin{array}{l}0.042^{* * * *} \\
(0.003)\end{array}$ & $\begin{array}{l}0.042 * * * \\
(0.003)\end{array}$ & $\begin{array}{l}0.024 * * * \\
(0.004)\end{array}$ & $\begin{array}{l}0.018^{* * * *} \\
(0.004)\end{array}$ \\
\hline Post-secondary, non-Tertiary & $\begin{array}{l}0.021 * * * \\
(0.004)\end{array}$ & $\begin{array}{l}0.021 * * * \\
(0.003)\end{array}$ & $\begin{array}{l}0.011 * * * \\
(0.003)\end{array}$ & $\begin{array}{l}0.006 * \\
(0.003)\end{array}$ \\
\hline First level Tertiary & $\begin{array}{l}0.017 * * * \\
(0.004)\end{array}$ & $\begin{array}{l}0.017 * * * \\
(0.003)\end{array}$ & $\begin{array}{l}0.011 * * * \\
(0.003)\end{array}$ & $\begin{array}{l}0.009 * * * \\
(0.003)\end{array}$ \\
\hline Second level Tertiary & $\begin{array}{l}0.011 * * * \\
(0.004)\end{array}$ & $\begin{array}{l}0.011 * * * \\
(0.004)\end{array}$ & $\begin{array}{l}0.006 * \\
(0.003)\end{array}$ & $\begin{array}{l}0.003 \\
(0.003)\end{array}$ \\
\hline Upper Tertiary & $\begin{array}{l}0.002 \\
(0.004)\end{array}$ & $\begin{array}{l}0.003 \\
(0.004)\end{array}$ & $\begin{array}{l}0.003 \\
(0.004)\end{array}$ & $\begin{array}{l}0.003 \\
(0.004)\end{array}$ \\
\hline Observations & 105,298 & 105,298 & 104,485 & 92,563 \\
\hline R-Squared & 0.094 & 0.096 & 0.172 & 0.177 \\
\hline
\end{tabular}

The "primary" class of educational status is the omitted benchmark. Sample survival indicates the marginal effects of the covariates on the survival across waves. Clustered (for country) standard errors in parentheses

$M S$ marital status levels also taken into account, $S H$ self-health levels also taken into account, $S M$ social meeting levels also taken into account, $L R$ placement on left right scale also taken into account $* * * p<0.01, * * p<0.05, * p<0.1$

Table 14 The average marginal effects of the ESS round on Depression

\begin{tabular}{lllll}
\hline Variables & $(1)$ & $(2)$ & $(3)$ & $(4)$ \\
& Base & Base +MS & Base+SH+SM & Base+SH+SM+LR \\
\hline ESS round & & & & \\
6 & -0.014 & -0.013 & -0.008 & $-0.008 *$ \\
7 & $(0.008)$ & $(0.008)$ & $(0.006)$ & $(0.005)$ \\
& $-0.024 * * *$ & $-0.022^{* * *}$ & $-0.017 * * *$ & $-0.013 * * *$ \\
Observations & $(0.007)$ & $(0.007)$ & $(0.005)$ & $(0.004)$ \\
R-Squared & 105,298 & 105,298 & 104,485 & 92,563 \\
& 0.094 & 0.096 & 0.172 & 0.177
\end{tabular}

The eight wave is the omitted benchmark. Sample survival indicates the marginal effects of the covariates on the survival across waves. Clustered (for country) standard errors in parentheses

$M S$ marital status levels also taken into account, $S H$ self-health levels also taken into account, $S M$ social meeting levels also taken into account, $L R$ placement on left right scale also taken into account

$* * * p<0.01, * * p<0.05, * p<0.1$ 
Table 15 The average marginal effects of the Placement on left right scale on Depression

\begin{tabular}{|c|c|c|c|c|}
\hline & (1) & (2) & (3) & (4) \\
\hline Variables & Base & Base + MS & $\mathrm{Base}+\mathrm{SH}+\mathrm{SM}$ & $\mathrm{Base}+\mathrm{SH}+\mathrm{SM}+\mathrm{LR}$ \\
\hline \multicolumn{5}{|c|}{ Placement on left right scale } \\
\hline 1 & 0 & 0 & 0 & $\begin{array}{l}-0.011^{* *} \\
(0.005)\end{array}$ \\
\hline 2 & 0 & 0 & 0 & $\begin{array}{l}-0.009 * \\
(0.005)\end{array}$ \\
\hline 3 & 0 & 0 & 0 & $\begin{array}{l}-0.009 * * \\
(0.004)\end{array}$ \\
\hline 4 & 0 & 0 & 0 & $\begin{array}{l}-0.005 \\
(0.005)\end{array}$ \\
\hline 5 & 0 & 0 & 0 & $\begin{array}{l}-0.013 * * * \\
(0.004)\end{array}$ \\
\hline 6 & 0 & 0 & 0 & $\begin{array}{l}-0.012 * * * \\
(0.004)\end{array}$ \\
\hline 7 & 0 & 0 & 0 & $\begin{array}{l}-0.015^{* * * *} \\
(0.004)\end{array}$ \\
\hline 8 & 0 & 0 & 0 & $\begin{array}{l}-0.006 \\
(0.004)\end{array}$ \\
\hline 9 & 0 & 0 & 0 & $\begin{array}{l}-0.013^{* *} \\
(0.006)\end{array}$ \\
\hline 10 & 0 & 0 & 0 & $\begin{array}{l}-0.006 \\
(0.006)\end{array}$ \\
\hline Observations & 105,298 & 105,298 & 104,485 & 92,563 \\
\hline R-Squared & 0.094 & 0.096 & 0.172 & 0.177 \\
\hline
\end{tabular}

The 0 class (extreme left) of the Placement on the left right scale is the omitted benchmark. Sample survival indicates the marginal effects of the covariates on the survival across waves. Clustered (for country) standard errors in parentheses

$M S$ marital status levels also taken into account, $S H$ self-health levels also taken into account, $S M$ social meeting levels also taken into account, $L R$ placement on left right scale also taken into account $* * * p<0.01, * * p<0.05, * p<0.1$ 


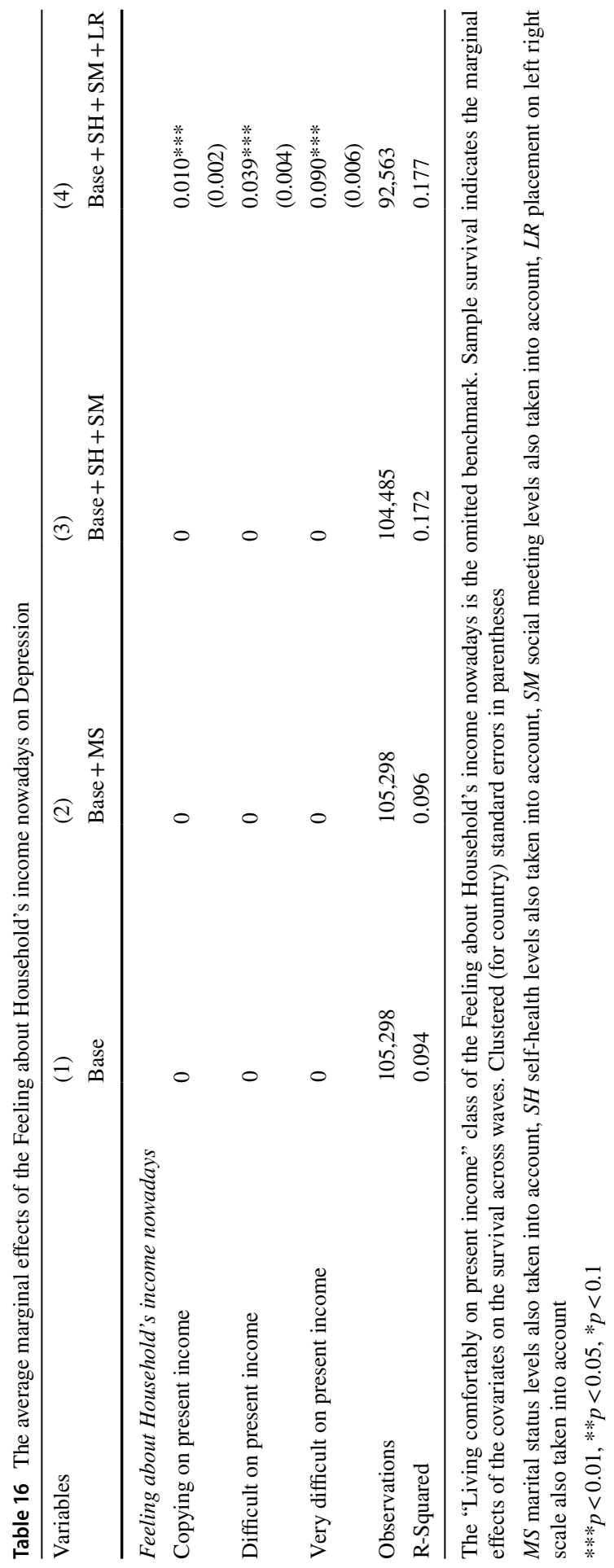


Table 17 The average marginal effects of the Month of interview on Depression

\begin{tabular}{|c|c|c|c|c|}
\hline \multirow[t]{2}{*}{ Variables } & (1) & (2) & (3) & (4) \\
\hline & Base & Base + MS & Base $+\mathrm{SH}+\mathrm{SM}$ & $\mathrm{Base}+\mathrm{SH}+\mathrm{SM}+\mathrm{LR}$ \\
\hline \multicolumn{5}{|c|}{ Month of interview } \\
\hline \multirow[t]{2}{*}{ February } & -0.006 & -0.007 & -0.006 & -0.006 \\
\hline & $(0.005)$ & $(0.005)$ & $(0.005)$ & $(0.005)$ \\
\hline \multirow[t]{2}{*}{ March } & -0.001 & -0.001 & 0.001 & -0.000 \\
\hline & $(0.009)$ & $(0.009)$ & $(0.008)$ & $(0.008)$ \\
\hline \multirow[t]{2}{*}{ April } & 0.008 & 0.008 & 0.003 & 0.005 \\
\hline & $(0.013)$ & $(0.013)$ & $(0.010)$ & $(0.012)$ \\
\hline \multirow[t]{2}{*}{ May } & -0.008 & -0.008 & -0.006 & -0.003 \\
\hline & $(0.014)$ & $(0.013)$ & $(0.012)$ & $(0.013)$ \\
\hline \multirow[t]{2}{*}{ June } & -0.014 & -0.014 & -0.012 & -0.008 \\
\hline & $(0.013)$ & $(0.013)$ & $(0.013)$ & $(0.016)$ \\
\hline \multirow[t]{2}{*}{ July } & $-0.031 * * *$ & $-0.031 * * *$ & $-0.027 * * *$ & $-0.026^{* * * *}$ \\
\hline & $(0.009)$ & $(0.009)$ & $(0.009)$ & $(0.009)$ \\
\hline \multirow[t]{2}{*}{ August } & $-0.024 * * *$ & $-0.023 * * *$ & $-0.020 * * *$ & $-0.014 * *$ \\
\hline & $(0.007)$ & $(0.007)$ & $(0.006)$ & $(0.007)$ \\
\hline \multirow[t]{2}{*}{ September } & -0.007 & -0.007 & -0.007 & -0.004 \\
\hline & $(0.006)$ & $(0.006)$ & $(0.005)$ & $(0.005)$ \\
\hline \multirow[t]{2}{*}{ October } & -0.006 & -0.006 & -0.005 & -0.003 \\
\hline & $(0.006)$ & $(0.006)$ & $(0.005)$ & $(0.005)$ \\
\hline \multirow[t]{2}{*}{ November } & -0.003 & -0.003 & -0.004 & -0.003 \\
\hline & $(0.004)$ & $(0.004)$ & $(0.004)$ & $(0.004)$ \\
\hline \multirow[t]{2}{*}{ December } & 0.005 & 0.004 & 0.004 & 0.005 \\
\hline & $(0.004)$ & $(0.004)$ & $(0.004)$ & $(0.004)$ \\
\hline Observations & 105,298 & 105,298 & 104,485 & 92,563 \\
\hline $\mathrm{R}$-Squared & 0.094 & 0.096 & 0.172 & 0.177 \\
\hline
\end{tabular}

The month of January is the omitted benchmark. Sample survival indicates the marginal effects of the covariates on the survival across waves. Clustered (for country) standard errors in parentheses

$M S$ marital status levels also taken into account, $S H$ self-health levels also taken into account, $S M$ social meeting levels also taken into account, $L R$ placement on left right scale also taken into account

$* * * p<0.01, * * p<0.05, * p<0.1$ 


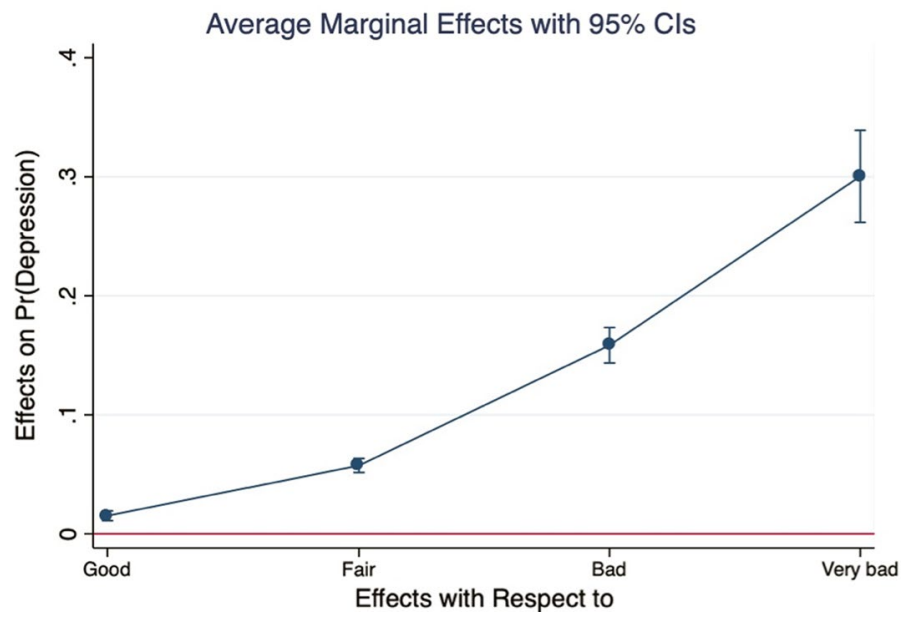

Fig. 2 The average marginal effects of the self-assessed health on Depression. Table 8, Column (4) estimate. The "very good" class of the self-health is the omitted benchmark

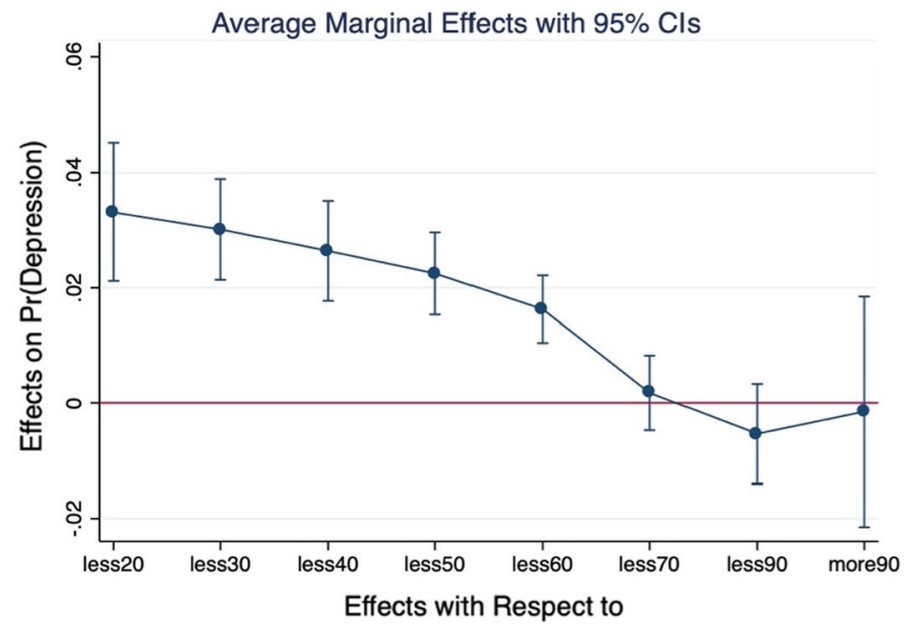

Fig. 3 The average marginal effects of Age class on Depression. Table 9, Column (4) estimate. The age class between 70-79 is the omitted benchmark 


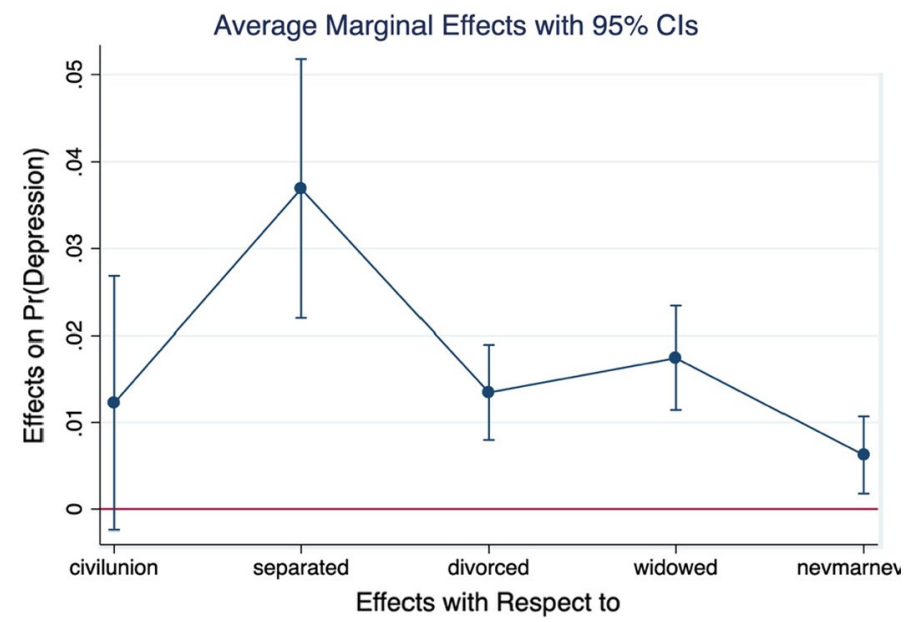

Fig. 4 The average marginal effects of the Marital status on Depression. Table 10, Column (4) estimate. The "married" class of marital status is the omitted benchmark

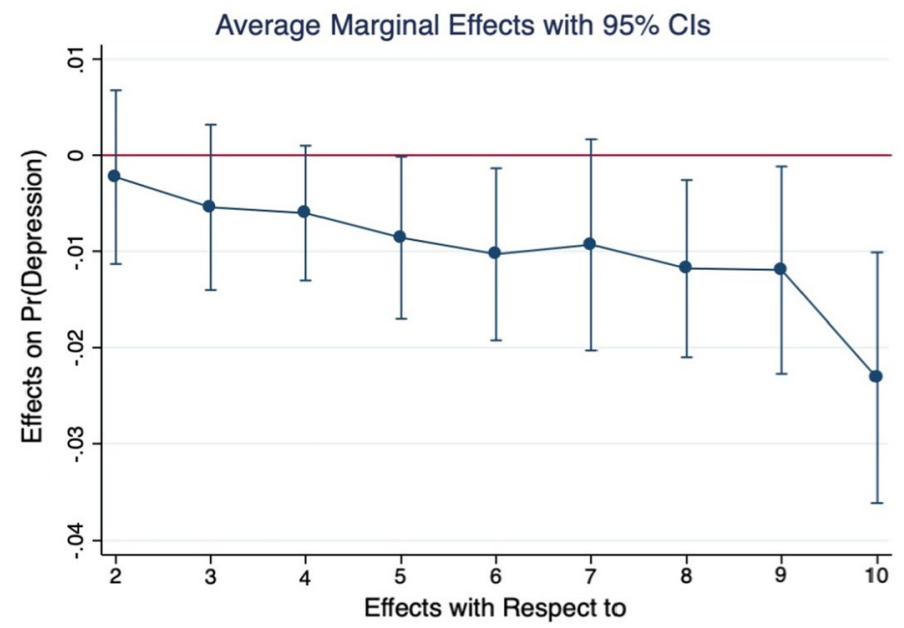

Fig. 5 The average marginal effects of Household's total net income on Depression. Table 11, Column (4) estimate. The first (lowest income) class of the household's net income is the omitted benchmark 


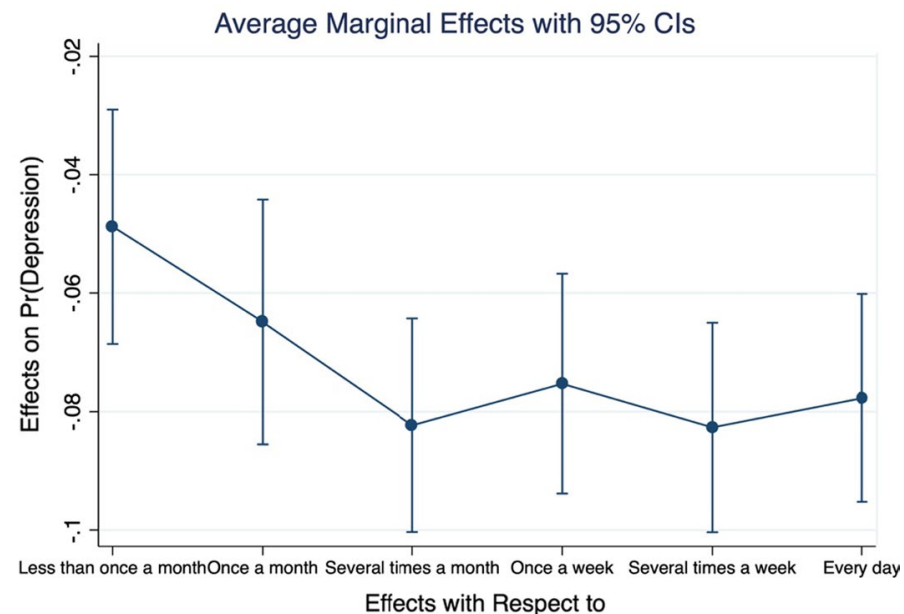

Fig. 6 The average marginal effects of the social meetings on Depression. Table 12, Column (4) estimate. The "never" class of the social meeting is the omitted benchmark

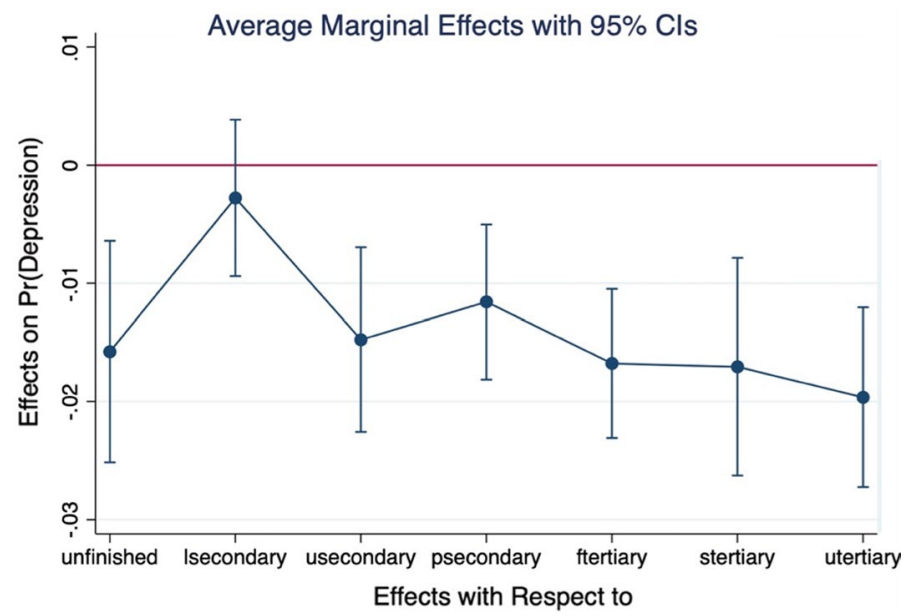

Fig. 7 The average marginal effects of Educational status on Depression. Table 13, Column (4) estimate. The primary class of education status is the omitted benchmark 


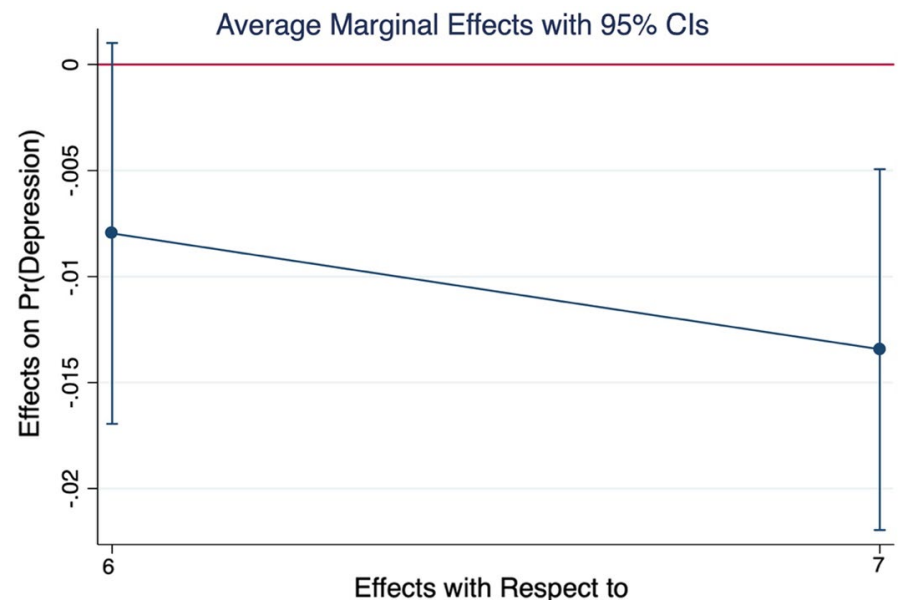

Fig. 8 The average marginal effects of the ESS round on Depression. Table 14, Column (4) estimate. The (last) eight wave is the omitted benchmark

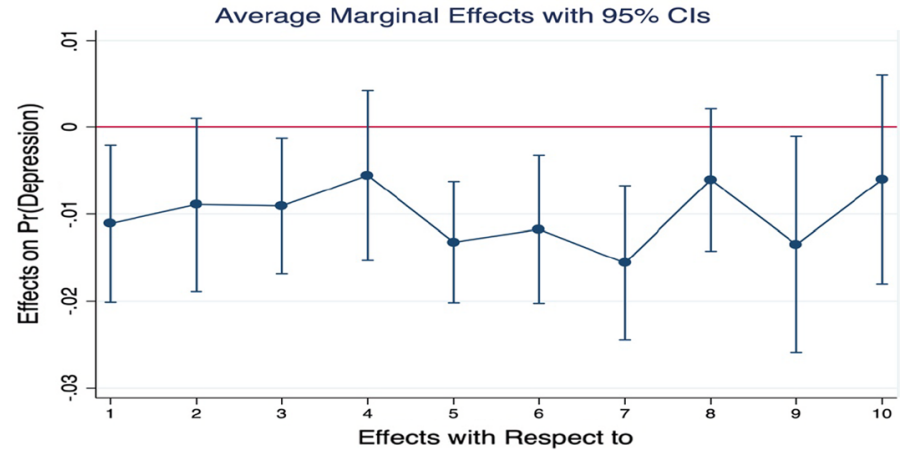

Fig. 9 The average marginal effects of the Placement on left right scale on Depression. Table 15, Column (4) estimate. The 0 class (extreme left) of the Placement on the left right scale is the omitted benchmark 


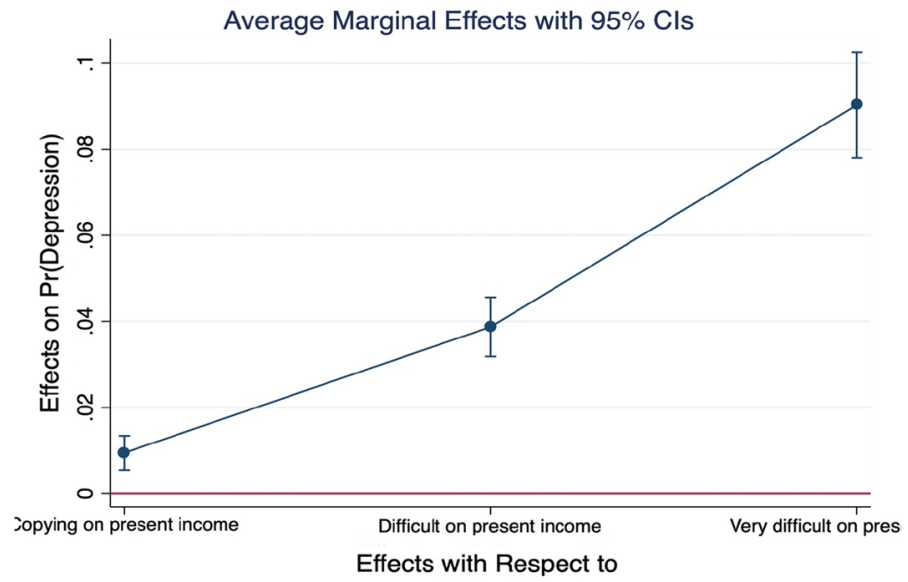

Fig. 10 The average marginal effects of the Feeling about Household's income nowadays on Depression. Table 16, Column (4) estimate. The "Living comfortably on present income" class of the Feeling about Household's income nowadays is the omitted benchmark

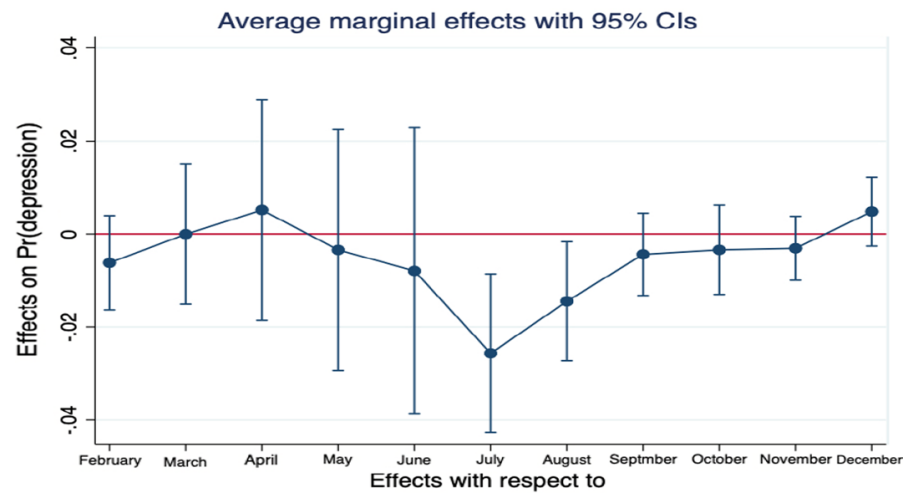

Fig. 11 The average marginal effects of the Month of interview on Depression. Table 17, Column (4) estimate. The month of January is the omitted benchmark

Funding Open access funding provided by Università degli Studi di Roma Tor Vergata within the CRUICARE Agreement.

\section{Declarations}

Conflict of interest The authors declare that they have no conflicts of interest.

Open Access This article is licensed under a Creative Commons Attribution 4.0 International License, which permits use, sharing, adaptation, distribution and reproduction in any medium or format, as long as you give appropriate credit to the original author(s) and the source, provide a link to the Creative Commons licence, and indicate if changes were made. The images or other third party material in this article are included in the article's Creative Commons licence, unless indicated otherwise in a credit line to the material. If material is not included in the article's Creative Commons licence and your intended use is 
not permitted by statutory regulation or exceeds the permitted use, you will need to obtain permission directly from the copyright holder. To view a copy of this licence, visit http://creativecommons.org/licen ses/by/4.0/.

\section{References}

Antoci A, Sacco PL, Vanin P (2007) Social capital accumulation and the evolution of social participation. J Socio-Econ 36(1):128-143

Alho H, Dematteis M, Lembo D, Maremmani I, Roncero C, Somaini L (2020) Opioid-related deaths in Europe: strategies for a comprehensive approach to address a major public health concern. Int J Drug Policy 76:102616

Bartolini S et al (2009) American decline in social capital and happiness. Is there a linkage? Mimeo. University of Siena

Becchetti L, Conzo G (2021) The gender life satisfaction/depression paradox, mimeo

Becchetti L, Pelloni A, Rossetti F (2008) Relational goods, sociability, and happiness. Kyklos 61(3):343-363

Becchetti L, Pelloni A (2013) What are we learning from the life satisfaction literature? Int Rev Econ 60(2):113-155

Becchetti L, Bachelet M, Pisani F (2019) Poor eudaimonic subjective wellbeing as a mortality risk factor. Economia Politica 36(1):245-272

Becchetti L, Trovato G, Bedoya DAL (2011) Income, relational goods and happiness. Appl Econ 43(3):273-290

Blanchflower DG, Oswald AJ (2004) Well-being over time in Britain and the USA. J Public Econ 88(7-8):1359-1386

Case A, Deaton A (2015a) Rising midlife morbidity and mortality, US whites. Proc Natl Acad Sci 112(49):15078-15083

Case A, Deaton A (2015) Rising morbidity and mortality in midlife among white non-Hispanic Americans in the 21st century. In: Proceedings of the National Academy of Sciences 112(49): $15078-15083$

Case A, Deaton A (2017) Mortality and morbidity in the 21st century. Brook Pap Econ Act 2017(1):397-476

Corneo G (2005) Work and television. Eur J Polit Econ 21(1):99-113

Corrado L, Weeks M (2010) Identification strategies in survey response using vignettes

Diener E, Sandvik E, Larsen RJ (1985) Age and sex effects for emotional intensity. Dev Psychol 21(3):542

Diez Roux AV (2017) Despair as a cause of death: more complex than it first appears, 1566-1567

Dow WH, et al (2019) Can economic policies reduce deaths of despair?. No. w25787. National Bureau of Economic Research.

Durkheim E (1951) Suicide: a study in sociology (1897)

Easterlin, RA, Angelescu L (2009) Happiness and growth the world over: time series evidence on the happiness-income paradox

Evans-Lacko S, Knapp M (2016) Cost of depression in the workplace across eight diverse countries-collectively US \$250 billion. LSE Health and Social Care

Ferrer-i-Carbonell A, Van Praag BMS, Theodossiou I (2011) Vignette equivalence and response consistency: the case of job satisfaction

Frey BS, Stutzer A (2002) What can economists learn from happiness research? J Econ Literature 40(2):402-435

Fujita F, Diener E, Sandvik E (1991) Gender differences in negative affect and well-being: the case for emotional intensity. J Personality Soc Psychol 61(3): 427

Gardner J, Oswald AJ (2007) Money and mental wellbeing: a longitudinal study of medium-sized lottery wins. J Health Econ 26(1):49-60

Gui B (1987) Eléments pour une définition d'économie communautaire. Notes Et Doc 19(20):32-42

Jenkins SP, Osberg L (2004) Nobody to play with? The implications of leisure coordination. Contrib Econom Anal 271:113-145 
Kessler RC, McGonagle KA, Swartz M et al (1993) Sex and depression in the National Comorbidity Survey. 1: lifetime prevalence, chronicity and recurrence. J Affect Disord 29:85-96

King G, Wand J (2007) Comparing incomparable survey responses: evaluating and selecting anchoring vignettes. Polit Anal 15(1):46-66

Masters RK, Tilstra AM, Simon DH (2018) Explaining recent mortality trends among younger and middle-aged white Americans. Int J Epidemiol 47(1):81-88

Matteucci N, Lima SV (2016) Women and happiness. In: Handbook of research methods and applications in happiness and quality of life. Edward Elgar Publishing

Nolen-Hoeksema S, Rusting CL (1999) Gender Differences in well-being. In: Kahneman D, Diener E, Schwarz N (eds) Well-being: the foundations of hedonic psychology. Russel Sage Foundation: New York

Randon E, Bruni L, Naimzada A (2008) Dynamics of relational goods. Int Rev Econ 55(1-2):113-125

Ruhm CJ (2019) Drivers of the fatal drug epidemic. J Health Econ 64:25-42

Ruhm CJ (2018) Deaths of despair or drug problems?. No. w24188. National Bureau of Economic Research

Stevenson B, Wolfers J (2008) Economic growth and subjective well-being: Reassessing the Easterlin paradox. No. w14282. National Bureau of Economic Research

Uhlaner CJ (1989) "Relational goods" and participation: Incorporating sociability into a theory of rational action. Public Choice 62(3):253-285

d'Uva TB, Jones AM, Van Doorslaer E (2009) Measurement of horizontal inequity in health care utilisation using European panel data. J Health Econ 28(2): 280-289

Weissman MM, Bland RC, Canino GJ, Faravelli C, Greenwald S, Hwu HG, Yeh EK (1996) Crossnational epidemiology of major depression and bipolar disorder. JAMA 276(4):293-299

Publisher's Note Springer Nature remains neutral with regard to jurisdictional claims in published maps and institutional affiliations. 